SALAZAR, Andrés. "La alteración de precios como fraude. Comentarios acerca del origen histórico del artículo 285 del Código Penal chileno y su interpretación”.

Polit. crim. Vol. 11, No 22 (Diciembre 2016), Art. 3, pp. 391-438.

[http://www.politicacriminal.cl/Vol_11/n_22/Vol11N22A3.pdf]

\title{
La alteración de precios como fraude. Comentarios acerca del origen histórico del artículo 285 del Código Penal chileno y su interpretación.
}

\section{The alteration of prices as fraud. Commentaries about the historical origins of article 285 of the Chilean Penal Code and its interpretation}

\author{
Andrés Salazar Cádiz* \\ Máster en Derecho Penal, Universidades de Barcelona y Pompeu Fabra. \\ andresalazarc@gmail.com
}

\begin{abstract}
"Duplex est pretium iustum, alterus legitimum, feu legale, vel decreto Principis, vel magistratus statutum est, considerata qualitate rei, \& aliis ómnibus circumstantiis: alterum vulgare, feu naturale, quod iuxta communem hominum aestimationem, \& iudicum constitutum est, non ex unius, vel alterius priuato assectu, id ex communi, iusta legem, pretia”.

Ioannis de Lugo. $1646^{* *}$.
\end{abstract}

\section{Resumen}

El presente artículo pretende aportar una visión alternativa al debate sostenido respecto del contenido y alcance del artículo 285 del Código Penal. Fundamentalmente, en este trabajo se sostienen tres tesis: El Código Penal chileno considera como una especie de fraude la mera manipulación de precios y dicha caracterización tiene un fundamento histórico relevante. En segundo lugar, que la exclusión de las coligaciones del texto nacional (con respecto a su fuente, el Código Penal español) tiene un fundamento político consistente con las preocupaciones sociales y debates legislativos que tuvieron lugar a fines del siglo XIX en nuestro país. Finalmente, se concluye que si bien el delito en cuestión no se trata de uno que se encuentre directamente enfocado en la protección de lo que hoy entendemos por libre competencia, dadas las propiedades de las conductas seleccionadas por el legislador,

\footnotetext{
* Agradezco al profesor del Centro de Regulación y Competencia de la Universidad de Chile, Francisco Agüero Vargas por su orientación en algunos de los temas aquí tratados. También, agradezco los comentarios del profesor de la Universidad de Barcelona, Dr. José Ignacio Gallego Soler. Evidentemente, los yerros que continúan presentes en este texto son exclusivamente atribuibles a quién suscribe este trabajo.

** "El justo precio puede ser de dos tipos: el legal y el natural. El precio legitimo o legal es aquel fijado por la ley o por el decreto del Príncipe o el magistrado después de tomar en consideración la calidad del objeto y el resto de las circunstancias de la compra y venta. El precio vulgar o natural, por otra parte, es aquel basado en la estimación y juicio común; no se basa en la estimación realizada por una persona en particular, sino en aquella realizada por la comunidad”. DE LUGO, Ioannis. Disputationes de Iustitia et Iure, Tomus Secundus, Lyon: Sumpt. Philippi Borde, Laurentii Arnaud et Claudii Rigaud. 1646, Disputatio XXVI, Sectio IV, N 38, p. 311 .
} 
SALAZAR, Andrés. "La alteración de precios como fraude. Comentarios acerca del origen histórico del artículo 285 del Código Penal chileno y su interpretación”.

se estima que ciertas prácticas colusorias (aquellas que tienen trascendencia en la fijación de precios en un determinado mercado) pueden ser igualmente alcanzadas por este tipo penal.

Palabras clave: Economía escolástica, acuerdos de precios, precio natural, fraude, coligaciones, libertad de industria, libre competencia, concurrencia, competencia perfecta, barreras de entrada.

\begin{abstract}
This article aims to provide an alternative view on the debate regarding the content and scope of article 285 of the Penal Code. Three theses are held fundamentally: The Chilean Penal Code considers the mere price manipulation as a kind of fraud and this characterization has a relevant historical basis. Secondly, that the exclusion of coalitions from the national text (with respect to its source, the Spanish Penal Code) has a political basis consistent with the social concerns and legislative debates that took place in the late nineteenth century in our country. Finally, it is concluded that while it is true that the offense in question is not one directly focused on protecting what we understand by free competition, given the qualities of the conducts selected by the legislator it is considered that certain collusive practices (those having transcendence in prices fixation in a given market) can also be reached by this offense.
\end{abstract}

Key words: Scholastic economy, Price fixing, natural Price, fraud, coalitions, free commerce, free competition, competition, perfect competition, barriers of entry.

\title{
Introducción
}

Además de provocar indignación colectiva, el denominado "caso farmacias" abrió una interesante disputa dogmática referida a la determinación del real alcance que puede otorgársele a una norma punitiva que hasta ese momento no había encontrado aplicación por parte de nuestros tribunales: nos referimos al delito de adulteración del precio de las cosas susceptibles de ser objeto de contratación, sancionado en los artículos 285 y 286 de nuestro Código Penal ${ }^{1}$.

\footnotetext{
${ }^{1}$ Los trabajos más importantes realizados entre nosotros respecto de dicho tipo penal y que justamente forman parte de la discusión a la que se hace referencia son los siguientes: HERNÁNDEZ, Héctor, "La punibilidad de la colusión (secreta) de precios en el derecho chileno", Polit. crim. Vol. 7, No 13 (2012), pp. 147-167; MATUS, Jean Pierre, "Acerca de la actual falta de punibilidad en Chile de los acuerdos de precios", Polít. crim. Vol. 7, No 14 (2012), pp. 318-356 y; MATUS, Jean Pierre, "De nuevo sobre la falta de punibilidad en Chile de los atentados contra la libre competencia de conformidad con el Art. 285 del Código penal. Algunos aspectos de la discusión con Héctor Hernández en Política Criminal", Polít. crim. Vol. 7, No 14 (2013), pp. 314-362. Este estudio fue finalizado con anterioridad a la fecha en que la Corte de Apelaciones de Santiago rechazara, a través de su resolución Rol No 3139-2015 de 29 de diciembre de 2015, los recursos de nulidad interpuestos por el Ministerio Público y por los querellantes en el citado caso, por lo cual dicha sentencia no formará parte del análisis en curso. De todas formas, los argumentos expuestos aquí pueden ser leídos como una crítica a dicha sentencia ya que ésta se alinea completamente con una de las posiciones dogmáticas que aquí se impugna, esto es, la posición planteada por el profesor Jean Pierre Matus. No obstante, cada vez que lo he estimado oportuno, he introducido ciertos comentarios a lo sostenido en aquel fallo en respectivas notas al pie.
} 
En términos muy resumidos, la cuestión central que pretende ser resuelta por los autores envueltos en dicha disputa es si acaso los artículos 285 y 286 CP son capaces, a través de su formulación, de subsumir y castigar conductas colusivas que tienen el efecto de alterar el precio de los bienes o servicios ofrecidos por los miembros de un cártel o si este tipo de conspiraciones sólo puede ser alcanzado por las normas administrativas contenidas en el artículo $3^{\circ}$ del DL No 211.

Pues bien, el presente trabajo pretende insertarse en dicha discusión. Sin embargo, los argumentos que se desarrollarán durante las próximas páginas discurren por un sendero muy distinto de aquel seguido por quienes han intervenido hasta la fecha en este debate. Y es que, sin perjuicio de que los razonamientos elaborados por quienes sostienen las posturas en tensión se hallan muy bien urdidos y fundamentados, a mi juicio, la discusión se ha autoimpuesto limitaciones temporales que le impiden llegar a conclusiones más satisfactorias.

En efecto, como se podrá apreciar más adelante, el delito previsto y sancionado en los artículos 285 y 286 del Código Penal acude a una serie de conceptos que pertenecen a una antigua tradición económica, tradición que debe ser tenida en cuenta a la hora de interpretar las mencionadas reglas si se quiere llegar a una cabal comprensión de lo que el legislador ha dispuesto a través de ellas.

En dichos términos, es obvio que una discusión basada en conceptos y concepciones económicas desarrolladas recién a partir de los últimos años del siglo XIX genere ciertas distorsiones y no sea capaz de apreciar el real alcance que debe otorgársele a las normas en cuestión.

Para intentar demostrar lo ya anunciado, en primer lugar, resumiré, brevemente, los aspectos más relevantes del debate sostenido entre nuestros autores a propósito de las referidas normas.

A continuación, centraré mi atención en aquellos conceptos incluidos en el texto del tipo penal que experimentan un significativo incremento en su potencial explicativo cuando ellos son reinterpretados a la luz de la concepción económica que les dio origen. En este orden de ideas, serán especialmente relevantes para este trabajo las nociones de "precio natural" y "fraude".

Posteriormente, complementaré dichos argumentos con consideraciones históricas más recientes y que guardan relación con las verdaderas razones que habrían tenido en consideración los autores del Código Penal para excluir del texto de los artículos 285 y 286 del CP la expresión "coligación”.

Concluida la revisión de los antecedentes históricos ya aludidos, se analizarán otras consideraciones conceptuales que han sido planteadas durante el reciente debate en torno al alcance de los mencionados preceptos. En este ámbito, de especial interés resultará comprobar la corrección de las tesis planteadas en torno al bien jurídico que se encontraría protegido por estas normas. 
SALAZAR, Andrés. "La alteración de precios como fraude. Comentarios acerca del origen histórico del artículo 285 del Código Penal chileno y su interpretación”.

Finalmente, se articulará una concepción del delito de adulteración de precios acudiendo a los conceptos ya analizados, esperando que dicha propuesta pueda servir para una mejor y más cabal comprensión de las reglas en cuestión.

\section{Breve descripción de la reciente discusión dogmática relativa al sentido y alcance del delito de alteración de precios.}

Los artículos 285 y 286 del Código Penal consagran el delito de adulteración de precios de la siguiente forma:

Art. 285. los que por medios fraudulentos consiguieren alterar el precio natural del trabajo, de los géneros o mercaderías, acciones, rentas públicas o privadas o de cualesquiera otras cosas que fueren objetos de contratación, sufrirán las penas de reclusión menor en sus grados mínimo a medio y multa de seis a diez unidades tributarias mensuales.

Art. 286. Cuando el fraude expresado en el artículo anterior recayere sobre mantenimientos u otros objetos de primera necesidad, además de las penas que en él se señalan, se impondrá la de comiso de los géneros que fueren objeto del fraude.

Si bien muchos de nuestros autores han prestado atención a dichas normas ${ }^{2}$, el estudio más detallado de ellas se ha producido sólo recientemente. Tal y como ya se mencionó, el análisis de éstas adquirió mayor profundidad a propósito del estallido del denominado "caso farmacias", fundamentalmente, luego de que el Ministerio Público decidiera iniciar una investigación en contra de los ejecutivos de las empresas implicadas en el acuerdo anticompetitivo, imputándoles a éstos la infracción de las referidas normas.

En este contexto, son los trabajos realizados por los profesores Héctor Hernández y Jean Pierre Matus los que han importado los esfuerzos más relevantes en nuestra doctrina por comprender de mejor forma el real contenido del delito de alteración de precios.

Resumiendo en demasía el intercambio de opiniones desarrollado por ambos autores, los puntos fundamentales del disenso se reflejarían en los siguientes aspectos: (1) en cuanto al bien jurídico protegido; (2) respecto del alcance que debe otorgársele a las expresiones "medios fraudulentos" y "fraude", incluidas en el texto de los artículos 285 y 286 CP; (3) en cuanto a la historia legislativa del precepto y a la real intención que podría atribuírsele a los autores de la norma, sobre todo, en lo que guarda relación con la decisión de excluir la

\footnotetext{
2 Destacan DEL RÍO, Raimundo, Derecho Penal, Santiago: Editorial Nacimiento, 1935, T. III, p. 242; ETCHEBERRY, Alfredo, Derecho Penal, $3^{\text {a }}$ Edición, Santiago: Editorial Jurídica de Chile, 1998, T. IV, pp. 280 y ss.; FERNÁNDEZ, Pedro Javier, Código Penal de la República de Chile esplicado y concordado, $2^{\mathrm{a}}$ Ed., T. II., Santiago: Imprenta Barcelona, 1900, pp. 34 y ss.; FUENSALIDA, Alejandro, Concordancias $i$ comentarios del Código Penal chileno, Lima: Imprenta Comercial, 1883, p. 301; LABATUT, Gustavo, Derecho penal, T. II., $7^{\text {a }}$ Ed., Santiago: Editorial Jurídica de Chile, 1983, p. 107; MERA, Jorge, Fraude Civil y Penal. El delito de entrega fraudulenta, $2^{\mathrm{a}}$ Ed., Santiago: Editorial Conosur, 1994, p. 90.; NOVOA, Eduardo, "La legislación penal económica", en: VV.AA., La nueva legislación y el desarrollo económico de Chile, Santiago: Editorial Universidad Católica, 1962, p.154.; recientemente, LONDOÑO, Fernando, "Aproximación histórico-comparada al Título VIII de la Ley de Mercado de Valores: bases para el reconocimiento de un contenido anti-manipulativo". Polit. crim. Vol. 10, No 20 (2015), pp. 390-467.
} 
Polít. crim. Vol. 11, No 22 (Diciembre 2016), Art. 3, pp. 391-438.

[http://www.politicacriminal.cl/Vol_11/n_22/Vol11N22A3.pdf]

palabra "coligación" de nuestras reglas de sanción y; (4) respecto del verdadero alcance que podría otorgársele a la expresión "precio natural".

Las diferencias constatadas llevan a los autores a plantear interpretaciones totalmente opuestas.

En este sentido, el profesor Hernández ha sostenido que las normas que son objeto de análisis tienen por finalidad velar por la libre competencia, siendo la pretensión del legislador proteger el libre juego de la oferta y la demanda, entendiendo que el sometimiento a esta ley constituye la forma legítima de determinar los precios en los mercados. En dicho contexto, la colusión orientada a la fijación artificial de precios constituiría uno de los medios fraudulentos que (genéricamente) proscribiría el respectivo tipo penal ${ }^{3}$. No obstante, Hernández agrega que, aún en el caso en que decidiésemos comprender de manera restrictiva el concepto de fraude, la colusión debería reconocerse como "la forma más elemental de falsificar la competencia" escenarios, debería entenderse que ella constituye una forma especial de "engaño concluyente" debido a que los autores del ilícito, por medio de su conducta, realizarían una declaración mendaz: que los precios de sus productos se encuentran establecidos como consecuencia de la competencia que éstos han enfrentado en el respectivo mercado. Consistente con lo anterior, Hernández entiende que "precio natural" sería aquel obtenido "bajo condiciones efectivas de competencia relativa", por lo tanto, una alteración de ese "precio natural" se daría cada vez que éste no se haya alcanzado bajo aquellas circunstancias 5 .

Por su parte, el profesor Matus ha planteado que el delito en cuestión tiene por objeto la protección de la "libre concurrencia". Bajo su concepción, dicha noción haría referencia a aquellas condiciones que posibilitarían la existencia de una multiplicidad de oferentes y demandantes en un determinado mercado (algo así como la posibilidad de "concurrir" a un mercado), mientras que el concepto "libre competencia" se reservaría sólo para describir un estado de cosas muy restringido: la concreta rivalidad que se desarrolla entre los oferentes (que ya han podido concurrir) en un determinado mercado ${ }^{6}$.

A partir de estas premisas, "precio natural" sería el que resulta del acuerdo libre entre oferentes y demandantes. Por lo tanto, una colusión que tenga por objeto la fijación del valor de venta de determinados productos no sería capaz de afectar a ese precio natural "en tanto se mantenga la libertad de los demandantes para aceptar o rechazar dichos precios", Por estas mismas consideraciones, los "medios fraudulentos" a que hace referencia el tipo penal, deberían ser interpretados restrictivamente. Así las cosas, este autor entiende que el único medio comisivo que la norma permitiría admitir sería el engaño. Por esta razón (y apoyándose en consideraciones de orden histórico-genéticas), postula que el artículo 285 $\mathrm{CP}$ debería ser interpretado como un delito que castiga el agio y otros engaños semejantes,

\footnotetext{
${ }^{3}$ HERNÁNDEZ, "La punibilidad", cit. nota no 1 , p. 154.

${ }^{4}$ HERNÁNDEZ, "La punibilidad”, cit. nota $\mathrm{n}^{\mathrm{o}}$ 1, p. 154.

${ }^{5}$ HERNÁNDEZ, "La punibilidad”, cit. nota no 1, pp. 163-164.

${ }^{6}$ MATUS, "De nuevo sobre", cit. nota no 1, pp. 316-319.

${ }^{7}$ MATUS, “De nuevo sobre”, cit. nota no 1, pp. 337-319.
} 
SALAZAR, Andrés. "La alteración de precios como fraude. Comentarios acerca del origen histórico del artículo 285 del Código Penal chileno y su interpretación”.

siempre y cuando, dichos embustes tengan por objeto restringir de la libre concurrencia de los agentes económicos ${ }^{8}$. Por último, dicha conclusión se vería reforzada por la decisión de eliminar del texto de la mencionada disposición toda referencia a las "coligaciones", circunstancia que, a su juicio, demostraría que las colusiones no contarían como medio fraudulento para nuestra ley ${ }^{9}-{ }^{10}$.

Ahora bien, debe tenerse presente que a pesar de las radicales diferencias que existen entre las tesis analizadas, también es posible constatar algunos factores comunes ${ }^{11}$.

\footnotetext{
${ }^{8}$ MATUS, "De nuevo sobre", cit. nota $n^{\circ} 1$, pp. 333-336.

${ }^{9}$ En este orden de ideas, de suma importancia serían las expresiones del comisionado Gandarillas, quien, en términos muy sucintos, habría justificado la exclusión de las coligaciones aludiendo al hecho que éstas no eran sino un reflejo de los derechos de libre asociación y de libertad de industria y, por lo tanto, serían legítimas. Sobre este aspecto se volverá más adelante.

${ }^{10}$ Cabe hacer presente que la reciente sentencia de la Corte de Apelaciones de Santiago que puso fin al denominado "Caso Farmacias" adhirió a la tesis postulada por el profesor Jean Pierre Matus. El fallo de la causa Rol 3139-2015 señala lo siguiente: “...discrepa esta Corte de esa concepción [de los recurrentes], pues en primer lugar en el artículo no es un tema menor que en la generalidad de las veces que el Código emplea los términos de "fraude" y "fraudulento" o "defraudar" sea en el sentido de "engañar, abuso de confianza, inexactitud consciente que prepara o produce un daño (...) la sola mención del término "medios fraudulentos" no es posible vincularla a un ejemplo decidor como en el caso del artículo 287. Por lo tanto, la interpretación armónica de las normas no puede ser un método que sirva para colegir el alcance del concepto". Al mismo tiempo la sentencia expresa que "...tampoco hay error de derecho en la interpretación que se ha dado a la expresión "medios fraudulentos", contenida en el artículo 285 del Código Penal en la sentencia impugnada, al entender que esas palabras aluden a medios de obrar motivados por el engaño, razón por la cual este recurso debe ser rechazado...".

${ }^{11} \mathrm{Si}$ bien existen otros argumentos que han sido planteados en el contexto de esta misma discusión hasta aquí hemos repasado los más importantes, siendo éstos los que inciden en el correcto entendimiento que debemos darle al artículo $285 \mathrm{CP}$. Por otra parte, los argumentos esgrimidos por el profesor Matus en orden a que habría operado una supuesta derogación tácita de los artículos 285 y 286 del CP no parecen avenirse con la real naturaleza de dicha institución, la cual ha sido correctamente caracterizada por el profesor Antonio Bascuñán R. Para una revisión de dicha posición, véase: BASCUÑŃN RODRÍGUEZ, Antonio, "Sobre la distinción entre derogación expresa y derogación tácita", Anuario de Filosofía Jurídica y Social, $\mathrm{N}^{\mathrm{o}} 18$ (2000), pp. 227-261. En este sentido, debe tenerse presente que la derogación constituye una solución de antinomias (de primer orden) la que opera cuando dos normas incompatibles parecen ser idóneas para la resolución judicial de un mismo caso, supuesto en el cual debe preferirse la ley posterior. Sin embargo, debe quedar claro que, la incompatibilidad a la que se hace referencia es la propia de las antinomias, esto es, se necesita la constatación de una contradicción deóntica entre las normas en conflicto. Tal y como señala Bobbio nos encontramos en presencia de una antinomia (de normas incompatibles entre sí) en un caso en el cual existen dos normas "que no pueden ser al mismo tiempo verdaderas", esto es, "en aquella situación en la que se encuentran dos normas, cuando una de ellas obliga y la otra prohíbe o cuando una obliga y la otra permite, o cuando una prohíbe y la otra permite un mismo comportamiento", teniendo ambas normas un mismo ámbito de validez. BOBBIO, Norberto, Teoría General del Derecho, Bogotá: Editorial Temis, 1987, pp. 184-190. Entonces, para que se pueda postular seriamente la existencia de una incompatibilidad tal que se haga necesaria la derogación tácita del artículo $285 \mathrm{CP}$, dada la vigencia del artículo $3^{\circ}$ del DL 211, deberíamos ser capaces de sostener que existe una contradicción deóntica entre lo dispuesto por dichas normas: pero esto, evidentemente, no es así: ambas disposiciones prohíben la fijación de precios, por lo tanto, se trata de normas plenamente compatibles. Sólo podría hablarse derogación tácita, por lo tanto, si una de las dos normas prohibiera la colusión de precios y otra la permitiera, pero este no es el caso. Seguramente, esta es la razón por la cual la Corte de Apelaciones de Santiago en su sentencia de 29 de diciembre de 2015, Rol No 3.139, recaída sobre el caso farmacias, al momento de acudir a la historia de la ley 19.911 no habla de derogación tácita, sino que acude (sin explicación ulterior) al artículo 24 del Código Civil (y no al artículo 52, como sería el caso), alusión que realiza sólo con fines retóricos, ya que de ella, posteriormente, no se extrae ninguna consecuencia relevante para definición del asunto controvertido.
} 
En primer lugar, huelga destacar que ambas coinciden en el hecho de que nuestros artículos 285 y 286 del CP., son el resultado de la fusión de los tipos penales contenidos en los artículos 461, 462 y 463 del Código Penal español de $1848^{12}$. De esta constatación deriva una importante consecuencia: la indefectible pertinencia del estudio de la legislación española que sirvió de antecedente para la codificación nacional.

En segundo lugar, otra característica común de las tesis en pugna la constituye, en mi opinión, su excesivo anclaje en nociones económicas "modernas", circunstancia que, como veremos, constituye un déficit transversal a ambas, debido a que las lleva a pasar por alto consideraciones histórico-económicas sumamente relevantes a la hora de interpretar las normas de que se trata. En este sentido, salta a la vista que en la discusión suscitada entre los profesores Matus y Hernández, poseen mucha incidencia algunas categorías conceptuales relativas al derecho de la competencia. Sin embargo, este derecho sólo fue desarrollado en propiedad durante el pasado siglo XX.

La mencionada inadvertencia, trae como consecuencia la necesaria descontextualización (en términos histórico-económicos) de conceptos centrales para la interpretación del referido tipo penal, tal como lo es, por ejemplo, la definición del "precio natural", circunstancia que fuerza a los autores a estipular significados que no necesariamente coinciden con el real sentido que debe otorgársele a dicha noción. De ahí que la estrategia seguida por éstos se traduzca, en mayor o menor medida, en resultados insatisfactorios.

Es así que, en las páginas siguientes, este déficit pretende ser subsanado, a través de la exposición de los conceptos económicos que se encuentran plasmados en (e inspiran a) nuestros artículos 285 y 286 del CP.

\section{Acerca de la conexión existente entre el texto del artículo 285 del Código Penal chileno, las categorías y conceptos introducidos por la teoría escolástica de los precios y la tradición legislativa europea en la lucha contra las prácticas colusorias.}

Como hemos visto, el debate referido al alcance que debe atribuírsele al delito de alteración del precio de las cosas, ha girado en torno a lo ocurrido en las postrimerías del siglo XIX. En este sentido, las investigaciones iniciadas por nuestros autores se han desarrollado teniendo a la vista, fundamentalmente, las Actas de las sesiones de la Comisión Redactora del Código Penal chileno y el tercer tomo de la obra "El Código Penal Concordado y Comentado" de don Joaquín Francisco Pacheco.

A partir de la evidencia que entregan ambas fuentes, parecería que existen buenas razones para no seguir indagando en la historia del precepto español y es que, con los datos

\footnotetext{
${ }^{12}$ Que la fuente de estos artículos la constituye el Código Penal español, es algo que se encuentra explícitamente reflejado en las Actas de la Comisión redactora. Particularmente clara resulta el Acta de la sesión 61 de 13 de octubre de 1871, donde se deja expresa constancia de la relación existente entre el artículo 275 del Proyecto de Ley (actual artículo 285 del CP chileno) y los artículos 461, 462 y 463 del Código Penal español. Sobre esto ver: Actas de las sesiones de la Comisión Redactora del Código Penal chileno, Santiago: Imprenta de la República de Jacinto Nuñez, 1873, pp. 119-120.
} 
SALAZAR, Andrés. "La alteración de precios como fraude. Comentarios acerca del origen histórico del artículo 285 del Código Penal chileno y su interpretación”.

proporcionados por dichos textos, en principio, sería posible arribar a resultados fundamentalmente correctos.

Sin embargo, la restricción autoimpuesta por los autores que participan del mencionado debate, los ha llevado a obviar del análisis antecedentes anteriores al contexto cronológico en que se desarrolló la codificación penal criolla, que resultan ser especialmente pertinentes para la labor hermenéutica que enfrentan.

El más enfático en desechar argumentos históricos que van más allá del referido período, parece ser el profesor Matus quien, a propósito de este punto, ha expresado que:

"En efecto, por una parte, parece muy difícil de aceptar que la Comisión Redactora del Código Penal de 1874 se hubiere anticipado casi tres lustros a la primera ley penal reconocidamente antimonopolios en nuestra órbita cultural, la Sherman Act, que entró en vigor en los Estados Unidos de América el año 1890. Y por otra, [que] la legislación hispana decimonónica en que la nuestra se basó no contemplaba sanciones a las infracciones a libre competencia...".

Precisamente, las dos afirmaciones contenidas en este párrafo son fundamentales a la hora de evaluar la corrección de las consecuencias a las que se ha arribado durante el reciente debate. Y ello porque, ambas (aún cuando en distintos grados) resultan ser refutables: mientras la primera aserción es completamente impugnable, la segunda, con ciertos matices terminológicos, también lo es.

$Y$ es que, como veremos a continuación, dichas aseveraciones implican negar reconocimiento a una larga historia de normas penales antimonopólicas que rigieron en el viejo continente y que se remontan hasta la antigüedad. Por su parte, en lo que se refiere a la segunda afirmación, ésta desconoce la existencia de antecedentes que dan cuenta del hecho de que los redactores de la norma española del año 1848, si bien no tuvieron en mente generar un derecho penal antitrust, como el desarrollado por la jurisprudencia norteamericana durante el siglo XX a partir de la escueta Sherman Act-incorporando los aportes económicos desarrollados por las escuelas de Harvard y de Chicago, en un contexto de Common Law- sí tuvieron a la vista normas españolas (especialmente, castellanas) que prohibían y sancionaban la manipulación de precios por parte de comerciantes que intervenían en un mismo mercado ${ }^{13}$.

Más tarde, volveremos sobre los factores que eventualmente podrían haber llevado a ignorar la evidencia sobre la existencia de normas antimonopólicas en el derecho europeo antiguo y medieval. Por lo pronto, y de la mano de las investigaciones realizadas por importantes autores extranjeros, iniciaremos la exploración de los antecedentes que demuestran que, precisamente, los artículos 285 y 286 del Código Penal chileno hunden sus raíces en una rica tradición normativa europea.

\footnotetext{
${ }^{13}$ Para un estudio de la evolución de la jurisprudencia norteamericana en la materia ver: KOVACIC, William y SHAPIRO, Carl, "Antitrust Policy: A century of economic and legal thinking”, Journal of Economic Perspectives, Vol. 14, No 1 (2000) pp., 43-60; También vase, PAGE, William, "Standard Oil and U.S. Steel: Predation and Collusion in the Law of Monopolization and Mergers", Southern California Law Review Vol. $85, \mathrm{~N}^{\mathrm{o}} 3$ (2012), pp. 101-131.
} 
Polít. crim. Vol. 11, No 22 (Diciembre 2016), Art. 3, pp. 391-438.

[http://www.politicacriminal.cl/Vol_11/n_22/Vol11N22A3.pdf]

\subsection{Precio natural, fraude y prácticas monopólicas según la economía escolástica.}

La influencia que tuvo la economía clásica en la configuración de nuestras sociedades capitalistas parece haber opacado por completo la importancia de las categorías conceptuales pre-modernas. Especialmente influyente ha sido Adam Smith, quien es reconocido como el padre de la economía moderna y cuyas ideas aun poseen gran influencia en el desarrollo de la ideología y la política neoliberal. No pretendemos restar méritos al connotado autor escocés, sin embargo la brillantez de su obra no puede encandilarnos de forma tal que lleguemos a pensar que todas las cuestiones económicas relevantes fueron abordadas por primera vez en sus trabajos.

Esto tiene particular importancia en lo que guarda relación con la teoría del monopolio. De hecho se ha llegado a afirmar que Adam Smith "disparó el primer cañonazo" en el ataque al monopolio", afirmación que no es sino fruto de la exageración. Y es que tal y como señala el profesor belga Raymond de Roover, Adam Smith no fue un pionero en esta materia:

"sino un lector voraz y maestro en el difícil arte de sintetizar. No solamente usó los materiales contenidos en los escritos técnicos de los fisiócratas franceses y de los mercantilistas ingleses, sino también las ideas y conceptos dispersos en grandes libros, filosóficos, históricos y legales, que son la herencia común de la civilización occidental. Por tanto, no es sorprendente que la teoría del monopolio de Adam Smith, lejos de ser original, pueda ser rastreada hasta la Política de Aristóteles"14.

En efecto, de acuerdo con los historiadores de la economía, la descripción del fenómeno monopólico y sus consecuencias, se encuentran registradas en fuentes que llegan hasta la antigüedad.

No obstante, tal y como constata de Roover "[1]os fundamentos reales de la teoría de los precios en general, y del monopolio en particular, no deben, sin embargo, buscarse entre los griegos y romanos, sino que en los sabios tratados de los doctores de la escuela escolástica" $"$.

Yendo al punto que aquí nos interesa, resulta necesario rescatar ciertos aspectos relevantes de la teoría escolástica de los precios y del monopolio, que tuvieron directa incidencia en la regulación penal de la actividad colusoria en Europa ${ }^{16}$.

\footnotetext{
${ }^{14}$ DE ROOVER, Raymond, "La Teoría del Monopolio antes de Adam Smith: Una revisión", Revista del Centro de Estudios Públicos, $\mathrm{N}^{\circ} 25$ (1987). Coincide con esta visión, pero sobre la base de antecedentes mucho más acotados MCNULTY, Paul, "A note on the history of perfect competition", Journal of Political Economy, Vol. 75, № 4 (1967), p. 396.

${ }^{15}$ DE ROOVER, "La Teoría", cit. nota no 14, p. 171.

${ }^{16} \mathrm{El}$ lector debe tener presente una importante consideración. Cuando se habla de economía escolástica o de la teoría escolástica del monopolio o de los precios, debe tener muy presente que con esto se hace referencia a una escuela y un pensamiento que trascendió con mucho al límite cronológico que le asignamos a la Edad Media. Como se verá a continuación, la influencia de dichos economistas se extendió durante toda la Edad Moderna y sus ideas influyeron decisivamente tanto en la legislación europea como en los economistas clásicos.
} 
SALAZAR, Andrés. "La alteración de precios como fraude. Comentarios acerca del origen histórico del artículo 285 del Código Penal chileno y su interpretación”.

En primer lugar, debe tenerse presente que, a diferencia de lo que ocurre con la ciencia económica actual, que pone el énfasis de su actividad investigativa en los efectos intrasistémicos de la actividad monopólica (la cual es tratada como una falla de mercado que genera ineficiencias distributivas), los economistas escolásticos centraron su preocupación en los problemas que la colusión de oferentes (y demandantes) implicaba para la justicia social ${ }^{17}$. En este sentido, a partir de la teoría de la justicia desarrollada por Tomás de Aquino, los escolásticos creían que los monopolios o las colusiones de agentes económicos que se unían para actuar de ese modo, afectaban a la justicia conmutativa, principio que debía regir las relaciones entabladas entre individuos, cuando éstas tienen por objeto el intercambio de bienes y servicios.

En este orden de ideas, los doctores escolásticos postularon que, para mantener este trato igualitario como eje de las relaciones comerciales entre los hombres, éstas debían encontrarse mediadas por el denominado "precio justo"18. Pero, ¿cómo se determina el precio justo? y ¿qué relación podría tener esta noción con los tipos penales que nos encontramos estudiando?

Pues bien, dependiendo de quién era el llamado a determinar el precio en los mercados, los escolásticos realizaron una distinción que será muy importante para nuestros efectos. Según estos autores, el precio justo podía ser de dos clases: el "precio legal" y el "precio natural" 19 .

El precio legal era definido como "aquel determinado por el príncipe, por medio de un decreto", siendo considerado por estos autores como una forma legítima (y justa) de fijar

${ }^{17}$ DE ROOVER, “La Teoría”, cit. nota no 14, p. 173.

${ }^{18}$ Tal y como señala Schumpeter, "precio justo", para esta teoría económica es aquel "que asegura la equivalencia de la justicia conmutativa" en las relaciones de intercambio que se sostienen entre individuos. SCHUMPETER, Joseph, Historia del Análisis Económico, Barcelona: Editorial Ariel, 2012, p. 131.

${ }^{19}$ DE LUGO, Ioannis, Disputationum de Iustitia et Iure, cit. nota introductoria, p. 311. Otra descripción útil de esta distinción se encuentra en la exposición realizada por Ludovico Molina (en adelante, Luís de Molina) en su obra De Iustitia et Iure, particularmente en su tomo segundo, conocido habitualmente como el "Contractibus", publicado el año 1601. De acuerdo con lo expresado en la disputatio CCCXLVII, el precio legal, es aquel "que viene fijado por la autoridad pública mediante ley o decreto público" (pretium rei est iustum, quoddam est lege publico ve decreto, per publica potestate taxatum), mientras que al precio "lo llaman natural porque nace de las mismas cosas independientemente de cualquier ley humana o decreto público, dependiendo de muchas circunstancias con las cuales varía (...) se caracteriza por no ser indivisible y presentar un cierto margen dentro del cual se cumple con la justicia, incluso cuando se consideran todas las circunstancias que "hic et nunc" concurren en el mercado" (fed naturale dicitur, quoniam ex ipsismet rebus, reclusa quacunque humana lege ac decreto confurgit, dependenter tamen á multis circunstantiss, quibus variatur (...) Quia ergo eusmodi pretium (...) configurit, fed circunstantiis, quibus variatur, pendet, \&, quod plus est, ab hominum affectu, \& aestimatione rerum pro fuo beneplacito, inde proficiscitur, ut non consistant in indivisibili, fet habeat certam latitudinem iusti ac comensurati merci, etiam spectatis circunstantiis omnibus, quae re ipsa hic \& nuc in commercio humano concurrut). DE MOLINA, Luis, Disputationes de Contractibus in Quibus Omnes, Atque Difficultates ad Hanc Materiam Pertinentes Resolutae, ac fumma con diligentia decisae adeò videntur. Venecia: Apud Matthiam Collosinum, \& Baretium Baretium, 1601, Disp. 347, p. 232. La traducción española se ha obtenido de DE MOLINA, LUIS, La Teoría del Precio Justo, CAMACHO, Francisco (Ed.), Madrid: Editora Nacional, 1981, pp. 159-160. También ver la traducción del capítulo 21 del De Iustitia et Iure de Leonardo Lessius, publicado en 1605, en: LESSIUS, Leonardus, "On Buying and Selling", DECOCK, Win (Trad.), Journal of Markets \& Morality, Vol. 10, № 2 (2007), pp. 465469. 


\section{Polít. crim. Vol. 11, № 22 (Diciembre 2016), Art. 3, pp. 391-438. \\ [http://www.politicacriminal.cl/Vol_11/n_22/Vol11N22A3.pdf]}

los precios en determinados mercados por medio de la intervención de la autoridad, ya sea en atención a la particular sensibilidad que poseían los bienes transados en aquellos mercados para la población o por las especiales condiciones imperantes en un lugar y momento determinados, condiciones que hacían necesaria la injerencia estatal en la economía $^{20}$. En términos actuales, el precio legal debería entenderse como una forma de regulación de mercado por la vía de la fijación del valor de los productos.

Por su parte, el precio natural era definido como "aquel determinado por la estimación común" de las personas que participan en los mercados ${ }^{21}$.

Así lo consideraron, entre otros influyentes autores de la Escuela Escolástica, Francisco de Vitoria $^{22}$, Leonardo Lessius ${ }^{23}$, Bernardino de Siena, Antonino de Florencia ${ }^{24}$, Luís de Molina $^{25}$, Juan de Lugo ${ }^{26}$, Juan de Matienzo, Diego de Covarrubias, Domingo de Soto ${ }^{27}$, etc. De esta forma, ya en el siglo XVI, la distinción entre precio legal y precio natural se encontraba ampliamente extendida y validada en Europa, siendo incluso adoptada con posterioridad por importantes autores protestantes del S. XVII como Hugo Grocio y Samuel von Pufendorf ${ }^{28}{ }_{-}^{29}$.

\footnotetext{
${ }^{20} \mathrm{Al}$ respecto, Diane Wood relata los siguientes ejemplos ocurridos en Inglaterra: “...en 1301, Eduardo I estableció los precios de unos alimentos y bienes manufacturados determinados para la ciudad de York. En la primavera de 1315, el Parlamento de Eduardo II, que se enfrentaba con las urgencias causadas por la gran hambruna, fijó los precios de los animales y otros alimentos. Eduardo III hizo lo mismo con los precios de los víveres más importantes "de acuerdo con el precio de mercado" en 1349, en el punto álgido de la peste negra". WOOD, Diane, El Pensamiento Económico Medieval, Barcelona: Editorial Crítica, 2003, pp. 201202. A partir de esta constatación, resulta patente el error en que incurre la sentencia Rol 3.193-2015 de la Corte de Apelaciones de Santiago cuando atribuye la paternidad del concepto "precio natural" a Adam Smith, de acuerdo con lo expuesto en el considerando tercero, página 9.

${ }^{21}$ Así por ejemplo San Bernardino afirmaba que el justo precio se determina por "la estimación que se hace, en común por todos los ciudadanos en una comunidad" en opinión del profesor de Roover, esto "es claramente el precio competitivo de un libre mercado" Al respecto: DE ROOVER, Raymond, "Economía Escolástica", Revista del Centro de Estudios Públicos, No 9 (1983), p. 93.

${ }^{22}$ VITORIA, Francisco, Comentarios a la secunda secundae de Santo Tomás, Tomo IV, BELTRÁN DE HEREDIA, Vicente (Ed.), Salamanca, Quaestio 77, Art. 1-2; Citado por POPESCU, Oreste, "Aspectos analíticos en la doctrina del justo precio de Juan de Matienzo (1520-1579)", Cuadernos de Economía y Ciencias Empresariales No 25 (1993), p. 69.

${ }^{23}$ LESSIUS, "On Buying", cit. nota no 19, pp. 466-468.

${ }^{24}$ Respecto de estos dos últimos autores ver: DE ROOVER, Raymond, San Bernardino of Siena and San Antonino of Florence. Two great economic thinkers of the middle ages, Boston: Harvard Graduate School of Business Administration, 1967, pp. 16-23

${ }^{25}$ MOLINA, "Disputationes", cit. nota n ${ }^{\circ}$ 19, p. 232.

${ }^{26}$ DE LUGO, "Disputationum”, cit., nota introductoria, pp. 311-315.

${ }^{27}$ Sobre estos tres autores véase: POPESCU, "Aspectos analíticos", cit. nota $n^{\circ} 22$, p. 69.
}

${ }^{28}$ Sobre esto DE ROOVER, "La Teoría", cit. nota $n^{\circ} 14$, p. 200; véase también, GRICE-HUTCHINSON, Marjorie, The School of Salamanca. Readings in spanish monetary theory, 1544-1605, Londres: Oxford University Press, 1952, pp. 65-78.

${ }^{29}$ De acuerdo con Popescu, esta distinción entre "precio justo legal" y "precio justo natural" también fue conocida y utilizada en América. Así, por ejemplo, Pedro de Oñate, defendió que la imposición del precio legal (aquel "tasado por la Ley") se justificaba en aquellos casos en que "es dificilísimo conmensurar el precio al valor de las cosas, a fin de que no se hagan compras y ventas según el juicio fraudulento de compradores y vendedores". Por su parte, Albornoz, justificó la "tasa del pan" (fijación legal de precios) dado el carácter monopólico de dicho mercado, ya que según éste a la "fuerza" producida por los monopolistas no se encuentra otro remedio que oponer la "fuerza" de la ley, para fijar a dichos mercaderes precios máximos. La 
SALAZAR, Andrés. "La alteración de precios como fraude. Comentarios acerca del origen histórico del artículo 285 del Código Penal chileno y su interpretación”.

A partir de esta definición y luego de un análisis profuso de los trabajos realizados por los mencionados autores, los historiadores económicos han llegado a una conclusión de gran interés para nuestro estudio: el precio natural definido por los escolásticos resulta ser equivalente a lo que hoy denominamos precio competitivo o de mercado ${ }^{30}$.

En síntesis, para los doctores escolásticos, cada vez que no existía un precio legal o fijado por la autoridad, "el precio natural o competitivo era el justo" para el específico mercado de que se $\operatorname{trate}^{31}$.

En concordancia con lo anterior, debe tenerse presente que estos autores ya habían estudiado las condiciones que influyen en la determinación de los precios en un mercado competitivo, haciendo especial alusión en sus registros a las circunstancias que afectan a la oferta y la demanda ${ }^{32}$.

Aquí cabe agregar otro aspecto esencial para nuestro trabajo. El precio natural o precio de mercado, según estos autores, era definido, en parte, negativamente: se trata de aquel determinado por la estimación común de los compradores en un determinado mercado, siempre que esa determinación se lograra efectuar con ausencia de coerción o fraude.

misma posición, asumió Luís López, quien veía en la regulación legal, una herramienta para controlar a los acaparadores y una forma de regular la venta de los artículos de primera necesidad. Al mismo tiempo, el mencionado historiador constató que los autores americanos también dominaron la noción de "precio justo natural". Para Popescu, en lo que se refiere al precio natural, "los escolásticos hispanoamericanos hicieron sus aportes teniendo a la vista tanto los escritos de sus maestros españoles como las reflexiones recogidas como observadores del proceso económico en las ferias y mercados de nuestras regiones. Sobre esto véase POPESCU, Oreste, "El pensamiento económico en la escolástica hispanoamericana", Económica, Vol. XXXII, No 2 (Julio- Diciembre, 1986), pp. 243-255.

${ }^{30}$ DE ROOVER, "La Teoría". cit. nota n 14, p. 173. Coincidiendo con este punto de vista, Schumpeter sostiene que el precio justo es equivalente al precio competitivo. Además, este autor señala que "frases como "precios naturales", "salarios naturales", etc. (...) "natural" significa sencillamente que se supone que no hay más perturbaciones que las que se podrían haber incluido en los datos mismos, o que nos proponemos estudiar un proceso o un estado tal como serían si se les dejara ser por sí mismos". Sobre lo anterior ver SCHUMPETER, “Historia del análisis”, cit. nota $\mathrm{n}^{\circ} 18$, pp. 137-138 y 152. Al respecto, Wood señala que "es casi seguro que el significado de esta idea era que el precio de mercado en curso era el resultado de la influencia impersonal de las leyes del mercado, dominado éste por la ley de la oferta y la demanda, además de los factores objetivos del coste y el trabajo que estaban implicados en la producción y la venta de los bienes", WOOD, “El Pensamiento”, cit. nota n²0, p. 193. Véase también, POPESCU, "El pensamiento económico”, cit. nota $\mathrm{n}^{\circ} 29$, pp. 253-255. Por último, cabe destacar que según Wood, los salarios también poseían un "precio natural", lo que parece ser compatible con nuestro artículo $285 \mathrm{CP}$. Sobre esto, WOOD, "El Pensamiento", cit. nota n²0, pp. 187-221.

${ }^{31}$ DE ROOVER, "La Teoría”, cit. nota no 14, p. 173.

${ }^{32}$ Nótese por ejemplo el siguiente pasaje escrito por Luys de Alcalá en 1546 respecto a la fijación natural y justa de los precios: "Verdad es empero que enesto del vender: también se deve considerar: que alli como la muchedumbre de los cómpradores/ y la necesidad de los tiempos/y la mucha costa/ industria y trabajo que le pone/ y la diversidad D las tierras/ y la poquedad de las mercaderías hazen subir los precios (como lo nota Siluel) alli tambien la poca costa/ y los tiempos prosperos/ y la muchedumbre de las mercaderías/ y poquedad delos compradores: los hacen bajar...". A cualquier persona podría parecer ésta una descripción bastante aproximada a los factores que intervienen en por el lado de la oferta y de la demanda en la formación de los precios. DE ALCALÁ, Luys, Tractado de los prestamos que se pastan entre mercaderes y tractantes: y por consiguiente delos logros/cambios/compras adeläntadas/ y ventas al fiado, Toledo, 1546. 


\section{Polít. crim. Vol. 11, No 22 (Diciembre 2016), Art. 3, pp. 391-438. \\ [http://www.politicacriminal.cl/Vol_11/n_22/Vol11N22A3.pdf]}

Ahora bien, ¿cuándo se puede decir que existe fraude en el precio de una cosa?. Los autores escolásticos dieron una respuesta a ello: existe fraude en el precio de las cosas cuando en su determinación concurre engaño o coacción o cada vez que los comerciantes acuerdan entre sí no vender las mercaderías sino a un precio convenido previamente por ellos.

En este sentido, conviene reparar en las palabras de Luys de Alacalá, quien en su "Tractato de los Prestamos..." de 1546, resumió lo que tanto en Castilla como en el resto de Europa, se entendía por fraude en el precio (natural) de las cosas:

"De manera que qualquier precio que comùmète cobra en la plaça/sera justo y excusable: no concurriendo fraude ni malicia (...) digo fraude: porque los que tienen las mercaderias/ o cosas de vender /se podrian entre si concertar de no vendellas sino a tal precio: y entonces aun entre todos corriesse aquel precio: no sería justo ni excusable..." 33 .

En este mismo orden de ideas, el influyente economista escolástico Luis de Molina, en su reconocido tratado De Iustitia et Iure, específicamente, en su libro II denominado el Contractivus, luego de especificar las circunstancias por las que puede variar el precio natural de las cosas, expresó lo siguiente:

"En resumen, el precio justo de las cosas depende principalmente, de la estimación común de los hombres de cada región; y cuando en alguna región o lugar se suele vender un bien, de forma general, por un determinado precio, sin que en ello exista fraude, monopolio, ni otras astucias o trampas, ese precio debe tenerse por medida y regla para juzgar el justo precio de dicho bien en esa región o lugar, siempre y cuando no cambien las circunstancias con las que el precio justificadamente fluctúa al alza o a la baja" ${ }^{34}$.

Nótese en el pasaje citado que, según el autor, los acuerdos de precios ("monopolios") 35 , no sólo se encuentran fuera de aquellas circunstancias que legítimamente influyen en la variación de precios en los mercados, sino que, además, se equiparan a los fraudes, astucias y otras trampas que afectan a la determinación de los precios.

La colusión para alterar precios, entonces, durante la economía escolástica, fue considerada y tratada como un fraude contra los consumidores ${ }^{36}$. Esta visión de los acuerdos de fijación

\footnotetext{
${ }^{33}$ DE ALCALÁ, Tractado de los prestamos, cit. nota $\mathrm{N}^{\circ} 32$, foja 5.

${ }^{34}$ MOLINA, La Teoría, cit. nota No 19, p. 169.

${ }^{35}$ Molina es explícito en la inclusión y tratamiento de la colusión por acuerdo de precios dentro del concepto de Monopolio como se indica en la Disputatio CCCXLV del Contractivus. Al respecto ver: MOLINA, "La Teoría", cit. nota $\mathrm{N}^{\circ} 19$, p. 140.

${ }^{36}$ En este sentido, también puede acudirse a los escritos de San Bernardino de Siena (1380-1444), quien si bien no conoció la distinción entre precio natural y precio legal, si adoptó una visión social de los precios, los cuales, de acuerdo con la visión escolástica que compartía, se fijaban por la comunidad en el contexto de un mercado libre. De esta forma, según la visión de este doctor "ni los compradores, ni los vendedores tenían [por sí mismos] ningún control sobre el precio, el cual era determinado por las fuerzas que interactúan en el mercado", en clara referencia a la oferta y la demanda. Por otra parte, Bernardino concebía a los monopolistas como aquellas personas que "a través de mecanismos fraudulentos y por acuerdos perniciosos, se juntaban para excluir a otros del comercio o para fijar el precio de sus mercancías por medio de la colusión en orden a incrementar sus beneficios, para su propio lucro, a costa del público". De forma coherente con su visión de la economía, y en particular de la concepción imperante sobre la manera en que se formaban los precios, San
} 
SALAZAR, Andrés. "La alteración de precios como fraude. Comentarios acerca del origen histórico del artículo 285 del Código Penal chileno y su interpretación”.

de precios, tal y como advierte de Roover, tuvo importantes consecuencias políticas ya que, de conformidad con "las enseñanzas de los Doctores, el monopolio en casi todas partes se consideró una ofensa criminal" $"$.

En definitiva, a través de la presente revisión histórica hemos logrado comprobar que las nociones de precio natural y de fraude, en el contexto de la economía escolástica, se encuentran intrínsecamente vinculadas por la existencia de acuerdos de fijación de precios. Como el lector podrá apreciar, la anterior caracterización coincide, en principio, con lo descrito por el texto del artículo 285 del Código Penal chileno. Sin embargo, antes de emprender un análisis de esta regla, debemos incorporar otros antecedentes que complementarán los hasta aquí consignados.

\subsection{Acerca de la proscripción penal de los acuerdos de precios en Europa: En particular, sobre los delitos de colusión contenidos en las Siete Partidas y en el Código Penal francés de 1810 como antecedentes legislativos de los artículos 285 y 286 CP.}

Consistente con su calificación de fraude, los ordenamientos jurídicos europeos, desde antiguo, castigaron las prácticas monopólicas por medio del derecho penal. En este sentido, el profesor Roman Piotrowski ha demostrado que las primeras normas penales destinadas a hacer frente a las conductas colusivas, se remontan hasta la época de la Roma imperial.

Algunos ejemplos de cuerpos jurídicos relevantes para nuestro estudio son la "lex Julia de annona" y el Edicto promulgado por el emperador Diocleciano, denominado "de pretiis rerum venalium”, del año 301 D.C. ${ }^{38}$. La lex Julia sancionaba a quienes se asociaren para incrementar artificialmente el precio del maíz y la conducta castigada por esta ley fue conocida como el "fraude de annona"39. Por su parte, el Edicto de Diocleciano sancionaba con la pena de muerte al que intentase, de cualquier forma, crear escasez artificial de mercancías y ciertas provisiones ${ }^{40}$.

Bernardino fue explícito en condenar estas prácticas. Sobre esto: DE ROOVER, San Bernardino, cit. nota $n^{\circ}$ 24, pp. 16-22. También véase: DE ROOVER, "Economía Escolástica”, cit., nota n 21, p. 93. Además, véase LANGHOLM, Odd, "Monopoly and market irregularities in medieval economic thought: traditions and text to A.D. 1500", Journal of the History of Economic Thought, V. 28, No 4 (2006), p. 395 y ss. Especialmente relevante el siguiente pasaje "The consensus of these scholars can be summarized as follows. Medieval authors (...) strongly condemned private monopolies established for personal gain, as well as collution among sellers for that purpose, Price discrimination, engrossing, forestalling, regrating, and other forms of speculations. The just Price was the current, competitive market price, free of all irregularities of these kinds and free of fraud and duress". Véase también: GORDON, Barry, Economic Analysis before Adam Smith: Hesiod to Lessius, Londres: Macmillan, 1975.

${ }^{37}$ DE ROOVER, "Economía escolástica”, cit. nota no 21, p. 117.

${ }^{38}$ PIOTROWSKI, Roman, Cartels and Trusts; Their Origin and Historical Development, Londres: George Allen \& Unwin LTD, 1933, pp. 98-111.

${ }^{39}$ Así lo registraron los comentaristas alemanes del S. XIV, Tiberius Decianus y Antonius Mattheus. Por ejemplo, Decianus indicaba en su Tractatus Criminalis de 1591 a propósito del "fraudantibus, aut onerantibus annonam" que "Item legem monopolii etiam puniebantur, qui pactiones inibant, ut species, et annona carius venderetur...". Citado por PIOTROWSKI, Cartels and Trusts, cit. nota no 38, p. 100.

${ }^{40}$ Otro interesante antecedente registrado por Piotrowski, es el que consta en la Constitución del emperador Zenon del año 483, en la cual se proscribían los monopolios acudiendo al siguiente título "Acerca de los monopolios y los acuerdos ilícitos de mercaderes o respecto de las prácticas ilegales de artesanos, maestros mecánicos y dueños de baños" (De monopoliis et de conventu negotiatorum ilícito vel artificum ergo 


\section{Polít. crim. Vol. 11, № 22 (Diciembre 2016), Art. 3, pp. 391-438. [http://www.politicacriminal.cl/Vol_11/n_22/Vol11N22A3.pdf]}

Por razones de extensión, no me será posible abordar aquí, de manera detallada, la historia de legislación penal europea orientada a sancionar las conductas monopólicas o los acuerdos colusorios $^{41}$. No obstante, debido a su pertinencia, hemos de detenernos en dos importantes reglas penales que rigieron en aquel continente y que, de conformidad con lo asentado por nuestros autores, habrían tenido algún grado de influencia en la redacción del delito de alteración de precios contenido en los artículos 285 y 286 del CP: nos referimos a la Ley II, Título VII, Partida V, de las Siete Partidas de Alfonso $\mathrm{X}^{42}$ y al Art. 419 del Código Penal francés de 1810.

Como sabemos, estas normas habrían influido en nuestro legislador a través de las concordancias realizadas por Pacheco, quien las habría considerado como antecedentes de los artículos 461 y 462 del Código Penal español de $1848^{43}$, reglas que, a su vez, fueron tomadas, posteriormente, como modelo para la redacción de nuestro delito de alteración del precio de las cosas.

Pues bien, la vinculación trazada por Pacheco, a mí juicio, demuestra que el delito que aquí nos ocupa posee una genealogía que lo une con normas que tuvieron por objeto la represión del fenómeno colusivo en Europa y, en dicha medida, la constatación de esa relación permite proveernos de mayores antecedentes a la hora de interpretar correctamente el alcance del ilícito en estudio.

Comencemos con el análisis de lo dispuesto en la norma incluida en las Partidas. El texto de esta regla disponía lo siguiente:

"Cotos é posturas ponen los mercaderes entre sí faciendo juras é cofradías que se ayuden unos con otros, poniendo precio entre sí, por cuanto dén la vara de cada paño, é cuanto dén otrosí el peso, a la medida de cada una de las cosas é non menos. Otrosí, los

\footnotetext{
laburumque nec non balneatorum prohibitis illicitisque pactionibus), titulo que se encuentra inserto en el Corpus Iuris Civilis. Sobre este cuerpo legal ver: PIOTROWSKI, Cartels and Trusts, cit., nota $\mathrm{n}^{\circ} 38$, pp. 111125.

${ }^{41}$ A modo de ejemplo, se nombran dos casos de interés: El primero se refiere al Edicto del 04 de Octubre de 1540 dictado por el Emperador Carlos V para Holanda. En el párrafo 7 de este Edicto puede leerse lo siguiente: "Asimismo, para prevenir, desde ahora en adelante, el daño que procede desde los monopolios y los contratos impropios que muchos mercaderes y vendedores hacen y usan en nuestras tierras para el detrimento del resto de los buenos y correctos mercaderes y vendedores y en contra del bien común; debemos ordenar y decretar y ordeno y decreto, que ningún mercader, vendedor ni ninguna otra persona promoverá la celebración de contratos, pactos o acuerdos que tengan carácter de monopolio o sean perjudiciales para el bien común, como el comprar todos los productos de una clase para acapararlas y luego venderlas a un precio excesivo $\mathrm{u}$ otras prácticas semejantes, bajo la pena de confiscación de los bienes y productos así adquiridos, además de una pena arbitraria" ver: COWEN, Denis, "A survey of the law relating to the control of monopoly in South Africa", South African Journal of Economics, Vol. 18 (1950), p. 129. El texto original puede ser consultado en PIOTROWSKI, Cartels and Trusts, cit. nota $\mathrm{n}^{\circ}$ 38, p. 181. Un segundo caso interesante de prohibición de la actividad monopólica o colusoria es el Estatuto de Monopolios (Statute of Monopolies) emitido por el parlamento británico en 1624, el cual declaró contra la ley todo monopolio no autorizado por la corona.

${ }^{42}$ Cabe destacar que este antecedente es debidamente notado por el profesor Matus, pero simplemente hace mención a él para luego descontarlo de su análisis y centrarse en las concordancias realizadas por Pacheco al Código Penal francés y al Código Penal austríaco. MATUS, "De nuevo sobre", cit. nota no 1, p.322.

${ }^{43}$ PACHECO, Joaquín Francisco, El Código Penal. Concordado y comentado, T. III. $5^{\text {a }}$ Ed., Madrid: Imprenta Santiago, 1881, p. 383.
} 
SALAZAR, Andrés. "La alteración de precios como fraude. Comentarios acerca del origen histórico del artículo 285 del Código Penal chileno y su interpretación”.

menestrales ponen coto entre sí, por cuanto precio dén cada una de las cosas que facen en sus menesteres. Otrosí, facen posturas que otro ninguno non labre de sus menesteres, si non aquellos que ellos reciben en sus compañías. E aun, que aquellos que así fueren recebidos que non acaben el uno lo que el otro oviere comenzado. E aun ponen coto en otra manera, que non muestren sus menesteres á otros, si non aquellos que descendieren de sus linajes dellos mismos. E porque se siguen muchos males dende, defendemos que tales cofradías, é posturas, é cotos, como estos sobredichos, nin otros semejantes dellos, non sean puestos sin sabiduría é otorgamiento del Rey, é si los pusieren, que non valan. E todos cuantos aquí adelante los pusieren, pierdan todo cuanto que ovieren é sea del Rey. É aun demás desto, sean echados de la tierra para siempre. Otrosí dezimos que los juzgadores mayores de la villa, si consentieren que tales cotos sean puestos; ó si después que fueren puestos, no los desfazer si lo sopieren; o no enviaren decir al Rey que los desfaga; que deben pechar al Rey cincuenta libras de oro" ${ }^{44}$.

Conforme a lo indicado por Brage, a través de este precepto se sancionaban con penas de confiscación y destierro, cuatro distintos tipos de confabulaciones conocidas en el derecho español del siglo XIII: (a) los denominados "cotos" que consistían en "la coligación de los patronos o comerciantes para fijar el precio de las mercaderías"; (b) las "posturas" que eran los conciertos entre los menestrales (esto es, entre artesanos y fabricantes) "para determinar el precio que habían de exigir por los artefactos o ingenios que fabricaban o producían"; las cofradías, que consistían en acuerdos entre maestros y obreros "para que sólo pudiesen trabajar en sus industrias aquellos que hubiesen sido recibidos en su compañía" y finalmente; las juras, práctica que hacía surgir la obligación para los maestros de "enseñar sus oficios solamente a aquellos que perteneciesen a su mismo linaje" 45 .

Podemos ver, entonces, que la norma medieval tenida a la vista por Pacheco, ya sancionaba penalmente entre sus hipótesis típicas, ciertos acuerdos de fijación precios.

Precisamente, dicha característica ha sido resaltada por Miguel Cuerdo y María Dolores Sánchez, para quienes este delito sancionaba derechamente la colusión ${ }^{46}$, importando en la práctica "una garantía legal de cierto entorno competitivo" "47.

A mayor abundamiento, y en consonancia con lo ya expresado en estas páginas, los mencionados autores han afirmado que el delito de que se trata no constituyó un caso aislado en España, sino que éste se encontraba inserto en una tradición de origen medieval,

\footnotetext{
${ }^{44}$ Versión extraída de CUERDO, Miguel y SÁNCHEZ, Dolores, "Tradiciones Penales en la maquinación para alterar el precio de las cosas", Anuario de Historia del Derecho Español Tomo LXXXIV (2014), p. 311.

${ }^{45}$ BRAGE, Santiago, "Los Delitos de alteración de precios en nuestro derecho histórico", Dereito $\mathrm{N}^{\circ} 9$ (2000), p.14. En relación con lo anterior, cabe destacar que la citada norma se encuentra bajo el sugestivo epígrafe de "Cómo los mercaderes non deben poner cotos entre sí sobre las cosas que vendieren", antecedente que podría reforzar aún más la idea de que la norma se refería a la proscripción penal de la colusión. Sobre esto ver: REAL ACADEMIA DE LA HISTORIA, Las Siete Partidas del Rey Alfonso el Sabio. Cotejadas con varios códices antiguos (glosadas por Gregorio López), Tomo III, Cuarta y Quinta Partida, París: Leiconte y Lesserre Editores, 1843, p. 564.

${ }^{46}$ CUERDO/SÁNCHEZ, "Tradiciones penales", cit. nota no 44, p. 310.

${ }^{47}$ CUERDO/SÁNCHEZ, “Tradiciones penales”, cit. nota no 44, p. 311.
} 


\section{Polít. crim. Vol. 11, № 22 (Diciembre 2016), Art. 3, pp. 391-438. \\ [http://www.politicacriminal.cl/Vol_11/n_22/Vol11N22A3.pdf]}

en virtud de la cual se proscribió la actividad monopólica a través de una serie de normas punitivas similares a ésta ${ }^{48}{ }_{-}^{49}$.

Pero aún debe tenerse en cuenta otro factor en relación con este añoso delito: mientras las Partidas rigieron en España hasta $1822^{50}$, en nuestro país, sus normas extendieron su vigencia algunos años más, rigiendo hasta el inicio del proceso de codificación. Por lo tanto, es muy probable que para los juristas nacionales del S. XIX (en particular, para aquellos que tuvieron a su cargo la redacción del Código Penal de 1875) las normas que se encontraban incluidas en el mencionado cuerpo legal, no fueran del todo desconocidas e incluso hayan ocupado un lugar en su formación profesional ${ }^{51}$.

En segundo lugar, y complementando lo señalado respecto de la legislación española, es el turno de volver la mirada sobre otro antecedente europeo de nuestro delito de alteración de precios, de acuerdo a lo consignado en la obra de Pacheco: me refiero al Art. 419 del Código Penal francés de $1810^{52}$.

Sobre este punto cabe mencionar que existe importante evidencia que confirma que la referida regla también tenía por objeto sancionar criminalmente los acuerdos de precios consensuados entre competidores.

${ }^{48}$ CUERDO/SÁNCHEZ, “Tradiciones penales”, cit. nota no 44, p. 323.

49 A mayor abundamiento, la Novísima Recopilación de las Leyes de España en su Libro XII, denominado "De los delitos y sus penas: y de los juicios criminales", en su título 12, específicamente en sus ley 10 sancionaba criminalmente a quienes "hicieren conciertos, ligas y monopolios en sus tratos con perjuicio de las rentas Reales". De acuerdo con Cuerdo y Sánchez "Estas leyes son muy claras, utilizan la primera persona del real para fijar el sujeto que recibe el daño y caracteriza el delito. En la ley 10, se trata de aquellos que "haciendo liga y monopolio" se conciertan entre sí para "defraudar nuestras rentas" en aquellas cosas que son de trato. La pena es de destierro durante un año y la quinta parte del patrimonio del penado". En: CUERDO/SÁNCHEZ, “Tradiciones penales”, cit. nota n 44, p. 317.

${ }^{50}$ De todos modos, conforme registra José Antón Oneca, tras la anulación del Código Penal español de 1822 , las Partidas mantuvieron aplicación hasta mediados del S. XIX. Al respecto véase: ANTÓN ONECA, José "El Código Penal de 1848 y D. Joaquín Francisco Pacheco", Anuario de Derecho Penal y Ciencias Penales, Tomo XIX, Fascículo III (1966), p. 475. Pacheco vivió y trabajó en el proyecto de Código Penal de 1848, bajo la vigencia de las Partidas.

51 BRAVO LIRA, Bernardino, "La vigencia de las Partidas en Chile", Revista de Estudios HistóricoJurídicos, Vol. 10 (1985), pp. 43-105. El artículo citado es interesante, no sólo porque fija la fecha de vigencia de las normas penales incluidas en las Partidas hasta 1875, sino que además, da cuenta del fundamento teológico que inspira toda esta regulación. Respecto a la formación de los juristas americanos y chilenos, en particular, bajo los textos del Derecho Indiano (las Partidas y la Novísima Recopilación) véase: BRAVO LIRA, Bernardino, "El derecho indiano después de la independencia en América española", Historia, Vol. N 19 (1984), pp. 5-51; Ver además: ESPINOZA, Hernán, "La Academia de Leyes y Práctica Forense", Anales de la Universidad de Chile, $\mathrm{N}^{\circ}$ 65-65 (1947), pp. 413-458.

52 Esta norma señalaba lo siguiente: Art. 419. El que por hechos falsos o calumniosos divulgados intencionalmente entre el público, por medio de ofertas hechas a los mismos vendedores, por la reunión o coligación entre los principales tenedores de una misma mercancía o artículo, formada para no venderla o venderla sólo a cierto precio, o por otras vías o medios fraudulentos, hicieren bajar o subir el precio de los géneros, mercancías, documentos o efectos públicos, en más o menos suma de la que hubiere resultado de la libre y natural concurrencia 
SALAZAR, Andrés. "La alteración de precios como fraude. Comentarios acerca del origen histórico del artículo 285 del Código Penal chileno y su interpretación”.

Así, de acuerdo con las investigaciones realizadas por el profesor Piotrowski, el delito establecido en el Código Penal galo poseía un claro contenido antimonopólico, carácter que no sólo se desprendería de su texto, sino de sus inmediatos precedentes legislativos.

Y es que, según Piotrowski, el legislador francés habría decidido promulgar esta norma penal luego de haber constatado la ineficacia demostrada por la legislación postrevolucionaria destinada a desincentivar las conductas monopólicas y colusorias que habrían afectado a la sociedad francesa en aquel contexto temporal.

Ante tal fracaso, el parlamento francés habría optado por crear una norma de gran amplitud, que permitiera sancionar penalmente "todos los métodos destinados a crear un alza o baja del precio natural de los mercados (y no solamente al acaparamiento)”, asignándoles una pena privativa de libertad y multas ${ }^{53}$.

La anterior opinión puede ser complementada con los estudios de Francis Walker quien constató que el Tribunal de Casación francés aplicó la referida norma en varias oportunidades para sancionar acuerdos colusorios que tuvieron por objeto alterar el precio de bienes y servicios, calificando a dichas conductas como repugnantes por afectar "la libre y natural competencia en el comercio" $" 54$.

Además de lo ya revisado, resulta oportuno hacer referencia a otro Código europeo que, aún cuando no tuvo gravitación directa en la redacción del estatuto punitivo criollo, sí tuvo un ascendiente fundamental en el desarrollo del Derecho Penal moderno. Me refiero al Código Penal de Baviera del año 1813. Y es que la mencionada compilación de normas penal sancionaba penalmente un delito de acaparamiento (Aufkauf) con las penas de confiscación y destierro. Comentando tal norma, el influyente autor germano Paul Anselm von Feuerbach señaló que dicho ilícito:

“...se refiere a (...) toda acción de la que resulte la falta de tales mercaderías o que pueda poner al público en la necesidad de comprar las mismas a un precio mucho más alto que el del mercado (...) [e]l crimen puede cometerse (...) emprendiendo especulaciones tales que tengan por objeto anular la competencia libre entre vendedores y compradores, obteniendo de este modo el poder necesario para fijar el precio deseado a sus propias mercaderías (monopolio arbitrario)",55.

Llama la atención el hecho de que Feuerbach, en su análisis del delito, a mediados del siglo XIX, haya hecho alusión a lo que hoy denominamos "poder de mercado" como elemento necesario para que la colusión entre vendedores pueda tener el efecto de alterar el precio de

\footnotetext{
${ }^{53}$ PIOTROWSKI, Cartels and Trusts, cit. nota $n^{\circ}$ 38, pp. 337-339. Específicamente, se refiere a las críticas dirigidas contra la ausencia de resultados de las medidas decretadas en junio de 1791 y julio de 1793.

54 WALKER, Francis, "The law concerning monopolistic combination in continental Europe", Political Science Quarterly, Vol. 20, No 5 (1905), pp. 28 y 29. Especialmente interesantes son los casos en que el Tribunal de Casación sancionó al Cartel de productores de soda, de Yodo y la sanción de una colusión de los empresarios del transporte. Véase también: RIESENFELD, Stefan, "The legal protection of competition in France", California Law Review, Vol. 48 (1960), pp. 576-579.

${ }^{55}$ VON FEUERBACH, Paul Johann, Tratado de Derecho Penal Común Vigente en Alemania, Buenos Aires: Editorial Hammurabi, 1989, pp. 284-285. Lo destacado en cursivas corresponde al autor de este trabajo.
} 


\section{Polít. crim. Vol. 11, № 22 (Diciembre 2016), Art. 3, pp. 391-438. \\ [http://www.politicacriminal.cl/Vol_11/n_22/Vol11N22A3.pdf]}

mercado de los productos. Pero además, debe destacarse que el autor germano considera este delito como una especie de fraude. ${ }^{56}$

Para finalizar esta revisión de normas europeas, resta atender a la interpretación que los propios autores españoles otorgaron a su decimonónico tipo penal de alteración de precios. Al respecto, conviene citar los escritos de Alejandro Groizard, quién comentando los artículos 557 y 558 del Código Penal español de 1870 (que equivalen a los artículos 451 y 452 del Código Penal de 1848) expresó lo siguiente:

“...los motivos de los dos artículos á que consagramos este comentario (...) continúan siendo los mismos que dieron lugar al art. 419 del Código de Napoleón (...) [e]n el texto actual aparecen prohibidos y castigados todos los artificios empleados para alterar los precios naturales de todas las cosas que puedan ser objeto de contratación; y por lo tanto es de la prohibición genérica de los monopolios de lo que vamos a tratar (...) [uno] de los medios más usuales de alterar los precios naturales en los mercados es la coligación de los tenedores de cualquier mercancía, en virtud de la cual se obliguen á no enajenarla si no se les abona una cantidad convenida" ${ }^{257}$.

Además, el citado autor agregó en otro pasaje de su estudio que:

“...nuestra ley $(. .$.$) ha llevado con previsión plausible la protección de la libertad del$ tráfico á toda clase de hechos susceptibles a dar lugar a la entrega de un precio en cambio de la prestación de un servicio, hechos en los cuales la existencia de un ilegal monopolio puede existir con la misma finalidad que puede tener lugar en los contratos sobre compra y venta de géneros y mercancías" ${ }^{\text {"58 }}$.

De lo anterior se desprende que los autores españoles del siglo XIX se encontraban plenamente conscientes de que sus tipos penales eran capaces de castigar conductas monopólicas o colusivas y que aquellas reglas estaban vinculadas, a su vez, con otras normas penales del viejo continente, destinadas a sancionar el fraude fundado en la alteración de los precios de mercado.

Resumiendo lo hasta aquí descrito, del análisis de la historia del derecho europeo y en particular, a través del estudio de las normas citadas por Pacheco en sus concordancias,

\footnotetext{
${ }^{56}$ En efecto, Feuerbach considera que los antecedentes de este delito se encuentran en el ya mencionado crimen fraudatae de annonae del antiguo Derecho Romano, citando además al trabajo del influyente comentarista medieval Antonio Matthaeus, quien ya consideraba a la colusión para adulterar precios como un delito de fraude. De hecho, señala expresamente que "cuando las cosas que sean objeto del crimen son de las destinadas a la alimentación del cuerpo, se lo denomina de forma especial crimen fraudatae de annonae". Esto, evidentemente debe relacionarse a su vez con lo sostenido supra (Cap. II.1). Al respecto, véase: VON FEUERBACH, Tratado, cit. nota n ${ }^{\circ}$ 55, p. 284.

57 GROIZARD, Alejandro, El Código Penal de 1870 Concordado y Comentado, Tomo VII, Salamanca: Esteban-Hermanos, Impresores, 1897, pp. 383-398. Si bien este autor, se lamenta de que no haya sido consignada la coligación como un medio expresamente mencionado por la norma española (a diferencia de lo que ocurre con los falsos rumores), señala también que "siendo la norma tan amplia y clara, no era en rigor necesario". Por otra parte, si bien el autor señala que al requerir la ley un "artificio" la conducta del agente debería ser una más oculta o sutil, lo que nunca pone en duda el autor es que el fraude contemplado en dichos artículos permite castigar a los monopolios o acuerdos entre comerciantes.

${ }^{58}$ GROIZARD, El Código, cit. nota nº 57, pp. 393-394.
} 
SALAZAR, Andrés. "La alteración de precios como fraude. Comentarios acerca del origen histórico del artículo 285 del Código Penal chileno y su interpretación”.

podemos afirmar que la Comisión Redactora del Código Penal chileno no tuvo necesidad de adelantarse a la Sherman Act norteamericana para establecer un tipo penal que sancionara afectaciones a la comunidad ocasionadas por ciertas colusiones destinadas a alterar las consecuencias naturales del libre juego de las fuerzas del mercado.

Muy por el contrario, a los redactores de nuestro Código les bastó con apoyarse en la tradición existente desde antiguo en el derecho del viejo continente, tradición que proscribía y sancionaba penalmente ciertas prácticas monopólicas, en especial, aquellos acuerdos fraudulentos alcanzados entre mercaderes o productores, destinados a alterar el precio natural de las cosas, esto es, a manipular su precio de mercado.

\section{Acerca del claro alcance político de la eliminación de la expresión "coligación" en el contexto de la codificación criolla.}

Otro aspecto central del debate radica en la determinación de la real incidencia que habría tenido la decisión adoptada por nuestro legislador de excluir la voz "coligaciones" del texto de las normas en estudio.

Sobre este punto, Hernández, luego de analizar las Actas de la Comisión Redactora, llega a la conclusión de que la motivación que habrían tenido los legisladores al realizar dicha exclusión, sería la de evitar la punición de sindicatos y agrupaciones de patrones, ya que ellas no serían sino el reflejo del derecho de libertad de asociación ${ }^{59}$.

Por su parte, Matus, le otorga a este mismo antecedente una interpretación totalmente distinta: desde su punto de vista, el hecho de que se haya eliminado aquella expresión pondría de manifiesto que el legislador (adhiriendo a una concepción liberal de la actividad económica) le habría quitado toda connotación delictiva a las asociaciones de personas, las que, por lo tanto, no podrían ser consideradas como medio fraudulento. De esta forma, "los acuerdos de precios entre oferentes o demandantes del trabajo y de cualquier otra mercadería no sería punible, porque al alcanzarlo, los participantes ejercitaban sus derechos, esto es, su libertad contractual" "60. A partir de esto, el mencionado autor deriva, como consecuencia, que el delito del artículo 285 del Código Penal sólo sancionaría las alteraciones de precio logradas a través de medios fraudulentos como el agio ${ }^{61}$.

Dadas las repercusiones que dicho antecedente tendrá para las conclusiones de este trabajo, vale la pena citar aquí los argumentos utilizados por el comisionado Gandarillas para fundamentar la eliminación de la alusión a las coligaciones del texto de nuestro artículo 285 $\mathrm{CP}$, argumento al cual ambos autores le dan tan distinta interpretación:

“El señor Gandarillas manifestó que no creía justa la subsistencia del artículo 276 del proyecto, porque no es posible castigar el uso lejitimo de un derecho, como es el que cada cual tiene para determinar el precio de su trabajo. En esta materia no debe admitirse otro regulador ni correctivo que la misma libertad de industria de la cual

\footnotetext{
${ }^{59}$ HERNÁNDEZ, “La punibilidad de la colusión”, cit., nota nº 1, p. 151.

${ }^{60}$ MATUS, "De nuevo sobre", cit. nota $\mathrm{n}^{\circ} 1, \mathrm{p} .325$.

${ }^{61}$ MATUS, "De nuevo sobre”, cit. nota $\mathrm{n}^{\circ} 1$, p.326.
} 


\section{Polít. crim. Vol. 11, № 22 (Diciembre 2016), Art. 3, pp. 391-438. \\ [http://www.politicacriminal.cl/Vol_11/n_22/Vol11N22A3.pdf]}

solamente puede resultar una fijación equitativa de los valores. Lo único que merece castigo es el empleo de medios fraudulentos para abaratar o encarecer el precio del trabajo" 62 .

Por mi parte, puedo anticipar que los antecedentes que rodean el contexto histórico de la discusión legislativa apoyan la tesis de Hernández. Todos los registros tenidos a la vista refuerzan la idea de que lo que se quiso evitar fue castigar a las asociaciones de obreros por medio de un delito de colusión.

En primer lugar, en el contexto español, quienes han estudiado el antiguo delito del artículo 461 del CP de 1848, han expresado que tanto éste, como sus posteriores transcripciones en los Códigos penales de 1850 y 1870, poseían un claro contenido antisindical ${ }^{63}$. Así por ejemplo, José Almanza Pastor afirma que:

"Los Códigos penales de 1822, 1848, 1850 y 1870 acogen, bajo idéntica redacción al mismo precepto que tipifica el delito de huelga. Dicen así: "Los que se coligaren con el fin de encarecer el precio del trabajo o regular sus condiciones..."64-65.

Pero el tratamiento delictual de la huelga en España no fue un caso aislado. Tanto en Inglaterra como en Francia, Italia y Alemania, existieron en aquella época normas que establecían drásticas sanciones a quienes se reunieran con fines sindicales ${ }^{66}$.

Tan significativo como el hecho de que en el contexto europeo rigiesen disposiciones penales que sancionaban las coligaciones de empleados o trabajadores destinadas a alterar el precio del trabajo, resulta ser el contexto y la discusión legislativa que se generaba en aquel entonces en nuestro país.

Y es que en Chile, justo en el momento en que se tramitaba el Código Penal, comenzaba a adquirir fuerza el movimiento sindical y su impacto dejaría rastros en nuestra legislación. En este orden de ideas, note el lector la tremenda semejanza que existe entre el siguiente discurso obrero, registrado en 1873 y los argumentos expresados por el comisionado Gandarillas a la hora de justificar la eliminación de la referencia a las coligaciones del artículo $285 \mathrm{CP}$ :

\footnotetext{
${ }^{62}$ Actas de las sesiones, cit. nota ${ }^{\circ} 12$, p. 280.

${ }^{63}$ ALMANZA PASTOR, José Manuel, "La huelga laboral en España tras la modificación del artículo 222 del Código Penal español”. Revista de Política Social No 72 (1996), p. 53.

${ }^{64}$ Este autor agrega que "[e]l verdadero alcance de la prohibición, a nuestro juicio, se extendía a la más radical prohibición de todo posible pacto colectivo sobre condiciones de trabajo. Declaradas ilícitas cualesquiera formas de convenciones colectivas, por lo mismo, quedaban considerados ilícitos los conflictos colectivos, cuyas pretensiones se dirigieran a alterar las condiciones del trabajo, y con mayor motivo, la exteriorización violenta de tales conflictos colectivos". ALMANZA PASTOR, "La huelga laboral", cit. nota $\mathrm{n}^{\mathrm{o}} 63$, p. 55.

${ }^{65}$ La interpretación de Almanza es confirmada por una fuente directa como lo es Alejandro Groizard. En su comentario al Código Penal español de 1870, Groizard es explícito en reconocer que el Artículo 556 de dicho cuerpo legal (sucesor del artículo 461 del Código de 1848) prohíbe, bajo amenaza de sanción penal, la huelga. Al respecto véase: GROIZARD, El Código, cit. nota No 57, pp. 322-382.

${ }^{66}$ En este sentido, RAMOS PÉREZ-OLIVARES, Alfredo, "Aproximación histórica al tratamiento de la huelga en la España preconstitucional”, Saberes, Vol. No 4 (2009), p. 5.
} 
SALAZAR, Andrés. "La alteración de precios como fraude. Comentarios acerca del origen histórico del artículo 285 del Código Penal chileno y su interpretación”.

"De esta libertad, reconocida hoi (...) en todos los países cultos, ha nacido el derecho que los obreros tienen para declararse en huelga, cuando no están satisfechos con el salario que se les abona (...) [h] uelga quiere decir descanso, suspensión de trabajo, y es un medio empleado por los obreros para obligar a los patrones a elevar los salarios... Desde que nuestra Constitución garantiza la libertad de industria, es claro que nadie puede impedir a los obreros que suspendan su trabajo..."67.

Además, ya existía, a la época en que se desarrollaba el trabajo de la Comisión Redactora del Código Penal, un precedente legislativo importante: durante el año 1855 el Congreso había rechazado un proyecto de ley que intentó sancionar penalmente a las coligaciones de trabajadores. De acuerdo a lo que constata el historiador Hernán Ramírez Necochea, el texto del segundo artículo de ese proyecto establecía lo siguiente:

"Artículo $2^{\circ}$. Toda coalición de parte de los obreros para cesar de trabajar a un tiempo, para prohibir los trabajos de ciertos talleres, impedir que se dirijan y permanezcan en éstos últimos antes o después de ciertas horas, será castigado, si hubiere habido tentativa o principio de ejecución, con una prisión que no baje de quince días ni exceda de tres meses" ${ }^{\prime \prime}$.

En dicha ocasión, los argumentos que fueron utilizados por los parlamentarios para rechazar tal propuesta giraron nuevamente en torno a la idea de que el trabajador tenía derecho a disponer del "libre ejercicio de su trabajo e industria" $69{ }_{-} 70$.

${ }^{67}$ FELIÚ, Daniel, El Trabajo y las Huelgas de Obreros. Conferencias dadas en la escuela de adultos titulada "Blas Cuevas", Valparaíso: Imprenta de la Patria, 1873, p.18.

${ }^{68}$ RAMÍREZ NECOCHEA, Hernán, Obras Escogidas. Balmaceda y la contrarrevolución de 1981. Historia del movimiento obrero en Chile. Vol. I., Santiago: Editorial LOM, p. 371.

${ }^{69}$ RAMÍREZ NECOCHEA, Obras Escogidas, cit., nota no 68 , pp. 371-372.

${ }^{70}$ Aquí cabe hacer una importante aclaración respecto de que lo que se debe entender por "libertad de industria" en el contexto del S. XIX, de modo de evitar confusiones. El profesor Matus, al interpretar las palabras expresadas por el comisionado Gandarillas para eliminar la referencia a las coligaciones, pareciera entender a la libertad de industria como equivalente a la noción de libre comercio o libre mercado utilizada durante el S XX por la famosa Escuela de Chicago. Sin embargo, puesta en el contexto histórico al que nos referimos, la libertad de industria se trataba de un concepto desarrollado, en principio, para hacer frente a los antiguos y aún existentes Gremios feudales. Como sabemos los Gremios consistieron en "un sistema de oligopolios productivos legales, acordados entre las autoridades políticas urbanas y los maestros gremiales, titulares de los oligopolios, a quienes era cedida en exclusiva la capacidad de obraje, de manera privilegiada frente al resto de la mano de obra y por tanto, de forma monopolística, ajena al libre mercado, a cambio de que se sometiesen voluntariamente a las exigencias, principalmente económicas, de extracción del excedente, pero también sociales, políticas y culturales, etc., de dicho poder político". En este marco, los gremios tenían la posibilidad de establecer "autoridades internas, normativas propias y la capacidad de fijar precios y salarios...”. GONZÁLEZ ARCE, José, Gremios. Producción artesanal y mercado, España: Universidad de Murcia. 2000, pp. 19 y 20. En el mismo sentido, LASTRA, José Manuel, "Las corporaciones de oficio y la libertad de asociación en Francia", Revista de la Facultad de Derecho de México, T. XLIX, № 223-224 (1999) p. 225. Los gremios restringían la libre circulación del "factor trabajo" al controlar el proceso de iniciación al oficio en el sector comercial que dominaban, en virtud de sus privilegios. Al consagrarse la libertad de industria como el derecho de poder emprender todo tipo de actividad económica, se buscó, entre otras cosas, pasar desde una forma colectiva de fijación del precio del trabajo a una basada en la negociación individual de conformidad con el principio de la autonomía de la voluntad. Sobre esto véase WEBER, Max, Economía y Sociedad, $2^{\mathrm{a}}$ Edición, Ciudad de México: Fondo de Cultura Económico. 2008, pp. 558-561 y 585 a 588. Es así como comienzan las legislaciones nacionales a prohibir a los gremios con miras a crear un "mercado de trabajo". HOBSBAWN, Eric, La Era del Capital. 5a Ed., Buenos Aires: Crítica, pp. 42-44. En 


\section{Polít. crim. Vol. 11, № 22 (Diciembre 2016), Art. 3, pp. 391-438. [http://www.politicacriminal.cl/Vol_11/n_22/Vol11N22A3.pdf]}

A mayor abundamiento, no podemos obviar el hecho que, de manera paralela a la discusión del Código Penal, específicamente, entre los años 1871 y 1876, el Presidente Federico Errázuriz Zañartu envió al Congreso una serie de reformas constitucionales, entre las cuales se encontraban aquellas que buscaban profundizar garantías constitucionales como el derecho a reunión y de asociación, derechos que sin duda se vinculan con la posibilidad de ejercer de manera lícita las actividades sindicales ${ }^{71}$.

En resumidas cuentas, al analizar el contexto histórico y normativo en el que se encontraba situada nuestra Comisión Redactora, sólo se puede desprender, de manera consistente, que la eliminación de la referencia a las coligaciones tuvo por finalidad evitar la criminalización de agrupaciones de los trabajadores que negociaban el precio de su trabajo. Lo anterior se logra percibir con mayor claridad cuando se repara en el hecho de que la libertad de industria, en aquella época, era un concepto dotado de un contenido mucho más amplio del que le otorgamos en la actualidad, el cual se relacionaba estrechamente a la libertad de trabajo $^{72}{ }^{73}$.

este camino hacia la proscripción del sistema laboral feudal los más influyentes cuerpos legales franceses fueron el Edicto de Turgot de 1776 y la Ley de Chapelier de 1791. Por su parte, en España resulta indispensable considerar el Real Decreto CCLXII de 08 de junio de 1813, emitido por la Corte de Cádiz, el cual consagró la libertad que aquí se analiza, disponiendo que a través de él se removerían todas "las trabas que hasta ahora han entorpecido el progreso de la industria", decretando en particular que "todos los españoles y extranjeros avecindados (...) podrán libremente establecer las fábricas o artefactos de qualquier clase que les acomode, sin necesidad de perraiso ni licencia alguna” y que además “...podrán ejercer libremente qualquiera industria u oficio útil, sin necesidad de examen, título ó incorporación a los gremios respectivos". Cabe hacer presente que este decreto tuvo breve vida en España (fue dictado durante la ocupación francesa), pero sin duda, nos permite apreciar la vinculación existente entre libertad de industria y libertad de trabajo. Finalmente, debe tenerse presente que la libertad de industria y trabajo, fue reinterpretada por Mill quien planteó a su respecto una concepción que compatibilizaba la negociación colectiva con la libre competencia (desplegada en el mercado laboral). Sobre esto véase: MILL, John Stuart, Principios de Economía Política. $2^{\mathrm{a}}$ Ed., Ciudad de México: Fondo de Cultura Económica. 2006, pp.798-802. Por otra parte, Marx criticó duramente la idea de una supuesta "libertad de contratar" reconocida al trabajador individual ya que a través de ella el obrero quedaba a merced del capitalista al momento de definir las condiciones laborales. En este sentido, véase MARX, Karl, El Capital. Crítica de la Economía Política.

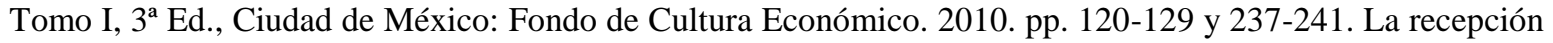
de la reinterpretación hecha por Mill y de la crítica socialista ante la cuestión social, generó un movimiento pendular que permitió entender que la libertad de industria y de trabajo no sólo era compatible con la posibilidad de negociar colectivamente las condiciones del mismo, sino que constituía un derecho del trabajador.

${ }^{71}$ Véase, MEYNET GONZÁLEZ, Alfredo, Estudio Histórico de las Reformas Constitucionales de la Administración Errázuriz Zañartu (1871-1876), Memoria para optar al grado de licenciado de ciencias jurídicas y sociales. Santiago: Universidad de Chile. 1946, pp. 96-103.

${ }^{72}$ En este orden de ideas, conviene citar las palabras del profesor de economía política más importante que tuvo nuestro país durante la segunda mitad del siglo XIX, Jean Gustave Courcelle-Seneuil, quien expresaba en 1858 el siguiente punto de vista: "Cuando se arroja una mirada sobre el conjunto de esfuerzos tan diversos por el cual se manifiesta la actividad voluntaria del hombre, se distingue un cierto número que tienen por objeto poner el mundo esterior al servicio de nuestros deseos, transformando los objetos materiales o conservándolos de un tiempo a otro, o transportándolos de un lugar a otro: el conjunto de estos actos ha sido calificado y designado bajo el nombre colectivo de industria humana, y esta industria entera entra a los estudios de la economía política". COURCELLE-SENEUIL, Jean Gustave, "Economía Política", Revista del Pacífico, Tomo I (1858), p. 197.

${ }^{73}$ De hecho, la tantas veces citada intervención del comisionado Gandarillas parece estar muy influenciada por el famoso dicurso pronunciado por el economista y parlamentario liberal francés Frédéric Bastiat ante la Asamblea Legislativa francesa el 17 de noviembre de 1849 conocido como el "Discurso sobre la represión de 
SALAZAR, Andrés. "La alteración de precios como fraude. Comentarios acerca del origen histórico del artículo 285 del Código Penal chileno y su interpretación”.

En definitiva, a través de su decisión, el legislador nacional evitó que se utilizaran normas destinadas a la sanción de acuerdos colusorios para reprimir uniones sindicales, marcando una diferencia con lo que ocurrió en otros ordenamientos jurídicos, como por ejemplo, es el caso del derecho norteamericano, donde se utilizó la paradigmática Sherman Act para perseguir a las agrupaciones de obreros que se formaron en dicho país ${ }^{74}{ }^{75}$.

\section{Respecto a la equivalencia existente entre los conceptos de libre competencia y libre concurrencia.}

El último punto que abordaremos referido al debate sostenido entre los profesores Hernández y Matus guarda relación con la determinación del bien jurídico protegido.

Para el primero de ellos el delito de adulteración de precios pretende evitar que el valor de las cosas se fije por factores ajenos al libre juego de la oferta y la demanda, por lo tanto, y en dicha medida, los artículos 285 y 286 del CP tendrían como objeto de referencia la

las coaliciones industriales" (Discours sur la répression des coalitions industrielles). En aquella oportunidad, el congresista alegó behementemente en contra de la penalización de los síndicatos contenida, justamente, en los artículos 413, 415 y 416 del Código Penal francés de 1810. Entre otros argumentos, Bastiat señaló que “...el hombre es libre para disponer de sus brazos como de su inteligencia, como de sus mercancías como de sus cosas. Una ley que impusiera una pena a un operario que se negare a trabajar porque encontraba escaso el jornal que se le entregaba, sublevaría las conciencias en el estado de la civilización que la sociedad ha llegado a alcanzar y lo mismo sucedería si esa ley obligase al fabricante a continuar las labores de su industria cuando los salarios absorbieran todos los productos del capital. El libre concierto de los obreros para abandonar el trabajo es una concecuencia lógica de aquel derecho individual. Un acto lícito en sí ejercitado por un individuo no puede cambiar de naturaleza porque sea practicado por muchos individuos a la vez. Lo que yo puedo hacer por la ley natural ¿por qué no he de poderlo hacer con otros? La voluntad colectiva de la coalición es producto de la voluntad individual de cada obrero: y el libre ejercicio de esta voluntad lleva consigo el libre ejercicio de aquella otra y es causa y fundamento del derecho a huelga". Esta alusión al famoso discurso de Batist ha sido extraída de GROISARD, El Código, cit. nota no 57, p. 348. Una versión integra del discurso puede encontrarse En: https://fr.wikisource.org/wiki/Discours_sur_la_répression_des_coalitions_industrielles. Finalmente, cabe hacer presente un dato de fundamental interés: Tal y como constata el historiador Sergio Villalobos, Jean Gustave Courcelle-Seneuil, precisamente, fue alumno en París de Frédéric Bastiat; ambos fueron seguidores de Jean Baptista Say y pertecieron a la escuela liberal de la economía francesa, escuela que fue capaz de comprender y defender el derecho a huelga. Lo anterior es reforzado por el hecho de que Courcelle-Seneuil se vio influido por el pensamiento de Mill, cuyo texto de Economía Política ayudó a traducir al francés. Por último, como ya hemos visto, Courcelle-Seneuil tuvo una influencia seminal en el pensamiento económico nacional a partir de la segunda mitad del S. XIX, pensamiento que pudo (debió) haber influido en Gandarillas quien fue abogado (miembro del partido liberal) y estudió en la Universidad de Chile cuando CourcelleSeneuil ya se encontraba en Chile a cargo de la cátedra de Economía Política. Sobre la relación entre Courcelle-Seneuil, Batist y John Stuart Mill véase: VILLALOBOS, Sergio, Los Comienzos de la Historiografía Económica de Chile, 1862-1940, Santiago: Editorial Universitaria, 1981, p. 28-31.

${ }^{74}$ Véase: MELTZER, Bernard, "Labor unions, collective bargaining and the antitrust law", Journal of Law and Economics, $\mathrm{N}^{\mathrm{o}} 152$ (1963), pp. 154-223.

${ }^{75}$ Por lo demás, debe tenerse presente que al momento en que se discutían las reglas que formarían parte del Código Penal chileno otras legislaciones ya habían dado un paso en este sentido. Al respecto, es posible citar la Ley Industrial alemana de 1869 que en su artículo 152 consignó señaló lo siguiente: “Artículo 152. Quedan abolidas todas las prohibiciones y las disposiciones penales contra las coaliciones o asociaciones formadas por empresarios, industriales, empleados u obreros de fábrica o de minas a fín de obtener los salarios más elevados o mejoras en las condiciones del trabajo, especialmente cesando de trabajar o despidiendo trabajadores". Sobre esto véase GROISARD, El Código, cit. nota n 57, p. 325. 
protección de la libre competencia. Por su parte, el segundo, afirma que existiría una diferencia conceptual entre libre competencia y libre concurrencia, siendo sólo este último bien jurídico al que estaría enfocada la protección otorgada por dichas normas. Según Matus esta diferencia conceptual habría sido inadvertida por Hernández, circunstancia que lo habría llevado a resultados erróneos.

Quisiera comenzar analizando, en primer lugar, el argumento esbozado por Matus, dada la trascendencia que su punto tiene para la definición de la controversia. Luego, se estudiará la propuesta interpretativa esbozada por Hernández.

Tal y como anticipamos, en su último estudio al respecto, Matus, apoyándose en un pasaje del trabajo del profesor Domingo Valdés, ha sostenido que existiría una diferencia analítica entre libre competencia y libre concurrencia. Así las cosas, el profesor Matus comparte el análisis realizado por Valdés, de acuerdo con el cual, para que exista libre concurrencia debería darse "una estructura de mercado en la que participe una pluralidad de oferentes", mientras que para que exista libre competencia bastaría con que confluyeran dos o más personas "aspirando a obtener la misma cosa"76.

A partir de esto, el mencionado autor llega a la conclusión de que libre competencia y libre concurrencia se encontrarían en niveles de análisis distintos. Consecuente con ello, Matus llega a afirmar lo siguiente: "no puede haber libre competencia sin libre concurrencia, pero sí puede existir libre concurrencia sin libre competencia, en el caso que los concurrentes, así lo decidan",77.

Esa diferencia conceptual que el profesor Matus cree haber descubierto en la distinción esbozada por Valdés lo lleva a plantear que el artículo 285 del CP se encontraría destinado a sancionar las maniobras fraudulentas que afectan a la libre concurrencia de oferentes y demandantes. Consistente con lo anterior, al dirigirse el ataque a personas concretas para que no "concurran" al mercado, Matus desprende que esas maniobras fraudulentas serían las de carácter engañoso. Un ejemplo de esto sería la conducta de esparcir rumores falsos que, si bien no fue incluida expresamente por el legislador nacional, se encontraría implícita en las referidas normas.

El razonamiento es sugerente pero errado. Como se demostrará a continuación, no existe una separación conceptual entre libre competencia y libre concurrencia. Lo anterior se sostiene básicamente en dos argumentos: uno de tipo etimológico y otro de tipo conceptual.

En cuanto al primer argumento, debe tenerse presente que desde una perspectiva históricolingüística, libre competencia y libre concurrencia, más allá de sus diferencias morfológicas, constituyen términos sinónimos: ambos hacen referencia al necesario estado de rivalidad que debe darse en los mercados para que éstos sean capaces de generar eficiencia económica.

Ahora bien, todo indica que esta relación de equivalencia se construyó con el tiempo luego de un proceso de transferencia y adaptación lingüística.

\footnotetext{
${ }^{76}$ VALDÉS, Domingo, Libre Competencia y Monopolio, Santiago: Editorial Jurídica, 2006, p. 80.

${ }^{77}$ MATUS, "De nuevo sobre", cit. nota n' 1, p. 325.
} 
SALAZAR, Andrés. "La alteración de precios como fraude. Comentarios acerca del origen histórico del artículo 285 del Código Penal chileno y su interpretación”.

Entre los historiadores económicos existe cierto consenso en que el Barón de Montesquieu, en su obra el Espíritu de las Leyes (de 1748), habría sido uno de los primeros autores que destacó las externalidades positivas generadas por la rivalidad que se suscita entre los agentes económicos que participan de un mismo ámbito comercial ${ }^{78}$. Para describir tal circunstancia, Montesquieu utilizó las siguientes palabras:

"C'est la concurrence qui met un prix juste aux marchandises et qui établit les vrais rapports entre elles" (es la concurrencia la que establece un precio justo para las mercaderías y establece las verdaderas relaciones entre ellas) ${ }^{79}{ }_{-}^{80}$.

El nuevo concepto pasó a Inglaterra y luego a Estados Unidos bajo la denominación de "competition", palabra que designaba de mejor manera la situación de "rivalidad" a la que aludía la francesa "concurrence". Por su parte, la palabra "concurrence", en lengua inglesa, tiene un significado diferente (acordar o cooperar) y, por lo tanto, dicha noción no fue empleada por los respectivos legisladores en los cuerpos normativos que buscaban proteger las condiciones necesarias para la existencia de un libre mercado ${ }^{81}{ }_{-}^{82}$.

A pesar de que el derecho de la competencia alcanzó su máximo desarrollo (tanto conceptual como jurisprudencial) en los Estado Unidos, fue la expresión "libre concurrencia" la que se impuso en Europa y trascendió con mayor fuerza en occidente. De

${ }^{78}$ En este sentido, DE ROOVER, "La Teoría", cit. nota no 14, p. 191. También hace alusión a este autor, POPESCU, "Aspectos Analíticos", cit. nota n 22, p. 113.

${ }^{79}$ MONTESQUIEU, Del espíritu de las leyes. México: Editorial Purrua, 1997, p. 306.

${ }^{80}$ Cabe hacer presente que existen datos que dan cuenta de usos relativamente similares de la misma. Así, por ejemplo, acerca del tránsito de la voz latina "concurriere" desde los escolásticos hasta la lengua francesa, véase: POPESCU, “Aspectos Analíticos", cit. nota n 22, pp. 90-94.

${ }^{81}$ En lengua inglesa "concurrence" es un sustantivo que se utiliza para designar un acuerdo o la ocurrencia simultanea de dos hechos. A su vez, "concurrence" viene del verbo "concur" que significa "tener la misma opinión" o "actuar juntos; de manera cooperativa". Etimológicamente se señala que "concur" proviene del latín "concurriere" que se traduce como "correr juntos". En cambio "competition" designa la situación de "empeñarse o luchar fuertemente con otro [striving or vying] por beneficios, precio, posición o las necesidades de la vida" o, más sencillamente, "rivalidad". Etimológicamente, "competition" viene del verbo "compete", el que a su vez proviene del latín "competere" que significa, precisamente "luchar con otros". Ver: MORRIS, William (Ed.), The American Heritage Dictionary of The English Language, Boston: Houghton Mifflin Company, 1976, pp. 271 y 277.

${ }^{82} \mathrm{Al}$ respecto cabe hacer presente que la traducción española de la obra de Jean-Baptiste Say, mantuvo la referencia a la libre concurrencia para designar lo que nosotros conocemos como libre competencia. Así por ejemplo, puede leerse en sus escritos que “...el precio corriente de todos los productos, por razón de la libre concurrencia, propende perpetuamente a aproximarse al precio de sus servicios productivos, esto es, a aproximarse a sus gastos de producción, a su precio natural, según expresión de Adam Smith", o, en otro pasaje "...como la mayor cantidad de pasajes y su mayor baratura son expresiones perfectamente sinónimas, los productores son más ricos, cuando los productos son más abundantes y menos caros. Digo los productores en general porque la concurrencia los obliga a dar los productos por lo que les cuestan...", SAY, JeanBaptiste, Tratado de Economía Política. Ó exposición sencilla del modo con que se forman, distribuyen y se consumen las riquezas, Tomo II, $4^{\text {a }}$ Edición, Madrid: Imprenta de don Francisco Martínez Dávila, 1821, p.376 y 479. Complementando lo anterior, tal y como lo constatado Juan Pablo Couyoumdjian, los primeros economistas chilenos, dada la intensa influencia que la escuela clásica francesa tuvo en nuestro país, a fines del S. XIX, entre otros factores, en razón de la cátedra de Economía Política dictada en la Universidad de Chile por el profesor Jean Gustave Courcelle-Seneuil, utilizaron en sus trabajos la expresión "libre concurrencia", en vez de "libre competencia". Sobre esto véase: COUYOUMDJIAN, Juan Pablo, "Importando modernidad. La evolución del pensamiento económico en Chile en el siglo XIX", Historia, $\mathrm{N}^{\circ}$ 48, Vol. 1 (enero-junio 2015), p. 68. 


\section{Polít. crim. Vol. 11, № 22 (Diciembre 2016), Art. 3, pp. 391-438. [http://www.politicacriminal.cl/Vol_11/n_22/Vol11N22A3.pdf]}

esta forma, las leyes que protegen las condiciones esenciales del libre mercado, en la mayor parte de nuestro entorno, aún mantienen el uso de la expresión "concurrencia" en vez de anglicismo "competencia" para designar al mismo grupo de normas, principios y fenómenos promovidos o proscritos por ellas. Así por ejemplo, a nivel legal, actualmente, tanto la ley francesa ${ }^{83}$ como la ley italiana $^{84}$, suiza ${ }^{85}$, canadiense ${ }^{86}$ y brasileña $^{87}$ se refieren a la protección de la concurrencia para designar lo que nosotros conocemos como libre competencia ${ }^{88}$.

Es más, en nuestro mismo derecho se ha entendido, sin lugar a dudas, que libre competencia y libre concurrencia son conceptos equivalentes. Entre otras consideraciones, lo anterior se concluye al analizar la exposición de motivos realizada por la junta militar al momento de establecer el D.L. $\mathrm{N}^{\mathrm{o}} 211^{89}$.

En efecto, mientras en el primer numeral de dicha exposición de motivos puede leerse que "...el monopolio y las prácticas monopólicas son contrarias a una sana y efectiva competencia...", en el tercer numeral del mismo acápite se señala que “...resulta necesario garantizar la libre concurrencia previniendo la existencia de monopolios y de las prácticas monopólicas". Luego, siendo el monopolio y las prácticas monopólicas el mismo denominador común que afecta tanto a la "libre competencia" como a la "libre concurrencia", basta acudir a una simple relación transitiva para comprobar la equivalencia de ambas nociones ${ }^{90}{ }_{-}^{91}$.

${ }^{83}$ En el Derecho Francés son dos los cuerpos normativos más relevantes en la materia. Por una parte se encuentra el Code de Commerce cuyo libro IV se denomina "de la liberté des prix et de la concurrence" se encuentra inserto el título IV que trata específicamente acerca de "la transparence, des practiques restrictives de concurrence et d'autres practiques prohibées". Por su parte, la autoridad sectorial (Autorité de la Concurrence) se encuentra consagrada en la "Loi de Modernisation de l'Economie" cuyo título segundo se denomina "Mobiliser la Concurrence comme Nouveau Levier de Croissansse" (activar a la competencia como nueva palanca de desarrollo").

${ }^{84}$ Legge $\mathrm{N}^{\circ} 287$ de 10/10/1990: Norme per la tutela della concurrenza e del mercato.

${ }^{85}$ Loi fédérale sur les cartels et autres restrictions à la concurrence, $\mathrm{N}^{\circ} 251$ de 06 de octubre de 1995.

${ }^{86}$ Cuyo caso es especialmente ejemplificador de lo que nos encontramos comentando debido a que su versión francesa se denomina "Loi sur la concurrence", mientras su versión inglesa se denomina simplemente "Competition Act". Esta norma se encuentra disponible en su versión bilingüe on line en: http://lawslois.justice.gc.ca/PDF/C-34.pdf.

${ }^{87}$ Lei $N^{o} 12.529$ de 30 de novembro de 2011, conocida como "Legislaçâo da defensa da concorrência".

${ }^{88}$ Por todo lo anterior, no es de extrañar que los autores del Código Penal español de 1848 hayan hecho expresa alusión a la "libre concurrencia" en el texto del artículo 462, debido a que existe constancia explicita a través de Pacheco que éstos ya habían tenido a la vista el texto del artículo 419 del Código Penal francés de 1810 que sancionaba entre otros a quienes esparcían rumores falsos o por cualquier otro medio fraudulento hacían variar (subir o bajar) los precios que habrían sido determinados por la competencia natural ("...des prix qu'aurait déterminés la concurrence naturalle...”). PACHECO, El Código Penal, cit. nota no 43, p. 386.

${ }^{89}$ Esta consideración ya la advertía el mismo Domingo Valdés quien señala en la misma obra citada por el profesor Matus que "[e]n el Derecho positivo chileno los términos libre competencia y libre concurrencia han devenido en equivalentes...". VALDÉS, Libre Competencia y Monopolio, cit. nota no 76, p. 80.

${ }^{90}$ Donde sí A (libre competencia) es igual a B (ausencia de monopolios y prácticas monopólicas); y B (ausencia de monopolios y prácticas monopólicas) es igual a $\mathrm{C}$ (libre concurrencia); entonces, A (libre competencia) es igual a C (libre concurrencia).

${ }^{91} \mathrm{Al}$ respecto, debe recordarse que la versión original del DL 211 estuvo fuertemente influenciado por la visión de los economistas chilenos vinculados a la escuela de Chicago. Al respecto véase: VV.AA., El Ladrillo. Las bases de la política económica del gobierno militar, $2^{\mathrm{a}}$ Edición, Santiago: Centro de Estudios 
SALAZAR, Andrés. "La alteración de precios como fraude. Comentarios acerca del origen histórico del artículo 285 del Código Penal chileno y su interpretación”.

Pero quizá mucho más determinante para la refutación de la distinción analítica planteada por el profesor Matus resulta la consideración de aspectos sustantivos bien tratados por la legislación, jurisprudencia y la doctrina económica y jurídica de la libre competencia.

Y es que lo que el profesor Matus designa como "libre concurrencia" es considerado por la doctrina especializada como una parte esencial e indisoluble de la libre competencia.

Como sabemos, toda la idea moderna del derecho de la competencia (llámese derecho antitrust, de la libre concurrencia o cualquiera sea su denominación) gira en torno a la persecución de un ideal teórico que denominamos "mercado perfecto" o, dicho de modo más preciso, "mercado en condiciones de competencia perfecta".

Pues bien, parte de los requisitos necesarios (y copulativos) para que pueda hablarse de un mercado competitivo es que en éste se de la necesaria atomicidad de oferentes y demandantes y que no existan barreras a la entrada de dichos agentes económicos ${ }^{92}$. De esta forma, para la doctrina especializada en la materia, si no existe lo que Matus denomina "libre concurrencia" nunca existirá un mercado en condiciones competitivas (y por ende no existirá "libre competencia").

Por otra parte, si bien el profesor Matus sostiene que podría existir libre concurrencia sin que existiera libre competencia, en lo que se refiere específicamente a afectaciones competitivas derivadas de la fijación de precios (que es de lo que hablamos cuando nos referimos a lo proscrito por el tenor literal del artículo $285 \mathrm{CP}$ ), debe reparase que ello olvida la importancia que posee para estos efectos lo que hoy denominamos "poder de mercado", ya que si tuvieran lugar acuerdos de precios sin que concurriera dicho factor entre los coludidos, en el contexto de un mercado abierto ("contestable"), sin barreras de entrada para nuevos "desafiantes", el acuerdo de precios sería inidóneo o efímero, pues las firmas cartelizadas no serían capaces de sostener la alteración de precios por mucho tiempo ${ }^{93}$.

Públicos, 1992, pp. 89-90. De esta forma, la relación trazada por la legislación de la Dictadura entre "libre concurrencia" y "libre competencia", no puede ser denostada de manera sencilla o calificada como un mal uso del lenguaje técnico proveniente de militares inexpertos en materias económicas. Sobre la extraordinaria influencia que tuvo Sergio de Castro y el resto de los "Chicago Boys" en la redacción original del D.L. 211, véase: BERNEDO, Patricio, Historia de la libre competencia en Chile. 1959-2010, Santiago: Ediciones Fiscalía Nacional Económica, 2013, pp. 59-68.

${ }^{92}$ En teoría los elementos que definen a un mercado competitivo son los siguientes: (1) atomicidad de la oferta y la demanda; (2) transparencia en el mercado o información perfecta -inexistencia de asimetrías informativas - (3) movilidad o inexistencia de barreras de entrada; (4) inexistencia de externalidades (un ejemplo clásico es la contaminación, que demanda asumir su costo en el proceso productivo); (5) homogeneidad de productos. Sobre estos requisitos véase: HYLTON, Keith, Antitrust Law. Economic Theory and Common Law Evolution, Boston: Cambridge University Press, 2003, pp. 4-8. Para un examen referido a la evolución de este concepto, su contenido y una defensa de su utilidad a pesar de su alto grado de abstracción e idealización, véase: STIGLER, George, "Perfect competition, historically contemplated", Journal of Political Economy, Vol. 65 (Febrero 1957), pp. 1-17.

${ }^{93} \mathrm{Al}$ respecto, véase: AMERICAN BAR ASOCIATION, Market Power Handbook, Competition Law and Economic Foundations, Estados Unidos: ABA Publishing, 2005, pp. 1-51. 


\section{Polít. crim. Vol. 11, № 22 (Diciembre 2016), Art. 3, pp. 391-438. [http://www.politicacriminal.cl/Vol_11/n_22/Vol11N22A3.pdf]}

Pero además, en términos más generales, ello olvida que muchos especialistas han definido, precisamente, la libre competencia enfatizando el mencionado aspecto. Así por ejemplo, el profesor Liefmann sostuvo que la competencia:

"no es solamente la presencia de muchos vendedores en el mercado. Uno podría definirla como la posibilidad de movimiento del trabajo y el capital. La competencia, al fin y al cabo, está presente mientras la aparición de un nuevo vendedor en una rama de la industria no quede excluida" 94 .

Justamente, entre nosotros, el profesor Domingo Valdés adhiere a una concepción similar de la libre competencia. En este sentido, el mencionado autor ha expresado que, a su juicio:

“...libre competencia significa libertad en el ingreso, explotación y salida de los mercados relevantes, cualquiera sea la modalidad de autonomía o heteronomía empleada para competir en el cabal cumplimiento del marco de principios y garantías constitucionales..."95.

Baste con lo señalado hasta aquí. Si bien es cierto, sería posible ahondar en el análisis de otros aspectos de la tesis elaborada por el profesor Matus ${ }^{96}$, lo importante es constatar que la libre competencia no se agota en la mera rivalidad que se da entre competidores en un determinado mercado, sino que dicho concepto incluye, entre otros factores, aquel que el profesor Matus denomina como "libre concurrencia" 97 .

${ }^{94}$ LIEFMANN, Robert, "Monopoly or competition as basis of a government trust policy", Quarterly Journals of Economics, № 29 (1915), p. 317.

${ }_{95}^{5}$ VALDÉS, Libre Competencia y Monopolio, cit. nota $\mathrm{n}^{\circ} 74$, p. 180. Lo destacado es nuestro.

${ }^{96}$ Sólo por mencionar algunas dudas que surgen a partir de la elaboración de su concepción del bien jurídico protegido por el art. 285, cabe preguntarse ¿cómo podría el agio afectar a la libre concurrencia de los agentes del mercado? Más bien, todo parece indicar que lo que busca quién esparce rumores falsos es atraer a la mayor cantidad posible de agentes económicos e influir en sus decisiones económicas hacia la dirección en que incide el autor del delito. Si esto es así, no se puede decir, en propiedad, que quién realiza agio restringa la libre concurrencia: muy por el contrario, la fomenta. Otra cosa es que la falsedad perjudique a la contraparte por incrementar las asimetrías informativas propias del mercado. Sin embargo, esa conducta afecta a un factor distinto de la teoría de los mercados perfectos que, como hemos visto, tiene que ver con la transparencia de los mercados.

${ }^{97}$ A mí juicio, quien mejor resume la forma correcta de ver el derecho de la competencia es Eleanor Fox, quien defiende una perspectiva según la cual aquellas normas tendrían por objeto "preservar la estructura competitiva (rivalidad) y la apertura de los mercados". En este orden de ideas Fox señala que "los defensores de esta perspectiva procesal" también valoran como eficiencia económica aquella que "produce lo que la gente quiere y necesita y que abraza la innovación y el crecimiento de firmas robustas". Al mismo tiempo, sostiene que estos autores son conscientes de que, si bien no se puede "gerenciar" la eficiencia, si es posible aumentar tanto ésta "como el bienestar económico (así como otras metas) por medio del mantenimiento de un medio ambiente que congenie" con aquellos competidores denominados "mavericks" (desafiantes molestos para los dominantes) y "trepadores". A su juicio, tras la protección de la competencia se encuentra la protección de "un ambiente que induce a las firmas a permanecer en rivalidad, a buscar caminos para reducir sus costos y para disputar el encuentro de lo que los consumidores quieren. Por lo tanto, preservar el acceso de los "outsiders", preservar la contestabilidad de los mercados respecto de altos niveles de concentración, valorar la diversidad, son mecanismos de eficiencia. Prevenir resultados ineficientes es también un objetivo [de la libre competencia], pero la primera, salvaguardar el proceso constituye la primera línea protectora de malos resultados. Esta perspectiva ha encarnado en los Estados Unidos el derecho de la competencia (antitrust law) por cerca de un siglo". FOX, Eleanor, "The efficiency paradox", en: PITOFSKY, Robert (Ed.), How the 
SALAZAR, Andrés. "La alteración de precios como fraude. Comentarios acerca del origen histórico del artículo 285 del Código Penal chileno y su interpretación”.

En lo que respecta a la tesis abonada por el profesor Héctor Hernández, si bien su posición acierta en cuanto a que las referidas normas proscriben los acuerdos colusorios, esto es, aquellos pactos que tienen por objeto reemplazar la contingencia propia que caracteriza al mecanismo normal de formación de los precios en los mercados, por la voluntad de las partes del acuerdo, desde nuestro punto de vista, debe tenerse presente un importante matiz. Habiendo constatado que el referido tipo penal constituye el reflejo de una antigua tradición económica europea que proscribía los acuerdos de precios, consecuentemente, debe tenerse en cuenta que su objetivo no es totalmente equivalente al que actualmente persiguen las normas de defensa de la competencia. Y es que, tal y como se ha hecho presente en las páginas anteriores, la moderna concepción de la libre competencia no sólo se preocupa de resguardar los intereses de los consumidores, sino que además fija su atención en las consecuencias intrasistémicas que trae aparejada la colusión (y por cierto, el resto de las conductas anticompetitivas). En otras palabras, parte de su preocupación pasa por desincentivar la ejecución de prácticas monopólicas porque ellas traen grandes ineficiencias: el cártel no sólo se apropia ilícitamente del excedente del consumidor, sino que, al poseer poder de mercado y tener la capacidad decidir sobre el precio al cual éste desea vender (en la búsqueda de incrementar sus beneficios), el monopolista producirá a un nivel subóptimo y generará lo que los economistas definen como una pérdida social neta, en atención que, en este escenario, se producirá una menor cantidad de transacciones mutuamente benéficas entre los demandantes y las firmas oferentes ${ }^{98}$.

Chicago School Overshot the Mark: The effect of Conservative Economic Analysis on U.S. Antitrust, New York: Oxford University Press, 2008, p. 80.

${ }_{98}$ Además de esto, debe tenerse presente que la libre competencia no sólo se enfoca en la colusión, sino también en otras conductas que restringen tal estado de cosas en los mercados. Así por ejemplo, se proscriben las conductas unilaterales de abuso de posición dominante, las prácticas concertadas e incluso la competencia desleal. El profesor Percy García, en el contexto de su legislación local, ha intentado entregar un concepto del bien jurídico-penal "libre competencia". De acuerdo con este autor: "[e]n el caso de los delitos contra la libre competencia, se protege concretamente la expectativa normativa que tienen los agentes económicos de poder participar y mantenerse en el mercado sin restricciones artificiales creadas por otros participantes. La defraudación de esta expectativa de conducta tiene lugar con la realización de las prácticas restrictivas de la competencia más graves". Si bien tiene el concepto postulado por este autor tiene la virtud de ajustarse de mejor forma a la concepción actual de la libre competencia, el intento de García debe ser visto con distancia ya que no se aviene totalmente a nuestra configuración normativa del contenido de dicho bien jurídico de acuerdo a los fines de nuestra legislación. Así por ejemplo, García parece entender que las reglas de la competencia protegen a los competidores. GARCIA CAVERO, Percy, Los Delitos contra la Competencia, Lima: Ara, 2004, p. 42. Esto no es del todo claro: no es una propiedad común de todas las conductas proscritas por el D.L. $\mathrm{N}^{\circ} 211$ el proteger a los competidores (y en ningún caso a los competidores ineficientes). Más bien, tal y como se consolidó en el derecho de la competencia norteamericano, todo parece indicar que tras las reglas del derecho de la comptencia no sólo se encuentra la idea de proteger la eficiencia de los mercados sino que también se encuentra presente el legítimo interés del consumidor en mantener mercados en condiciones competitivas. Sobre la clara decisión de proteger al consumidor a través de nuestro derecho de la competencia véase: BERNEDO, Historia, cit., nota ${ }^{\circ}$ 91, pp. 66-68; lo anterior, además se ve reflejado por una serie de normas pertenecientes a nuestro ordenamiento jurídico, las cuales indican que se busca la protección tanto de la eficiencia económica como del bienestar de los consumidores, tal como constata AGÜERO, Francisco, "Nuevos elementos para el debate sobre el bien jurídico libre competencia", Boletín Latinoamericano de Competencia", No 19 (Noviembre 2004) pp. 9-11. Para revisar la exposición paradigmática en el derecho norteamericano sobre este punto, donde la eficacia puede leerse como bienestar del consumidor ver: BORK, Robert, The Antitrust Paradox: A policy at war with itself. New York: Basic Books, 1978, pp. 81-89. 
Muy por el contrario, el espíritu de la legislación recogida por nuestra Comisión Redactora, dados sus antecedentes, pareciera centrarse más en los nocivos resultados que ocasiona el acuerdo de precios en la sociedad: encareciendo el nivel de vida, generando acaparamiento o escasez artificial, o restringiendo las posibilidades de acceso de consumidores necesitados de determinados bienes y servicios. En buenas cuentas, si bien ambas concepciones aluden a bienes jurídicos de carácter colectivo, la idea a la que parecieran adscribir las normas de los artículos 285 y 286 del CP gira en torno a la protección de los intereses de los consumidores ( $u$ oferentes, en el caso en que se consideren incluidas las prácticas monopsódicas), más que a las consideraciones sistémicas que se encuentran tras una concepción moderna de la libre competencia.

\section{El artículo 285 como un delito de fraude.}

A partir de lo que hemos visto hasta aquí, quisiera esbozar brevemente una interpretación del tipo penal del artículo 285 del CP.

De lo estudiado se desprende que la referida norma sanciona a quienes suscriben acuerdos para alterar el precio de las mercancías que puedan ser objeto de contratación y a quienes realizan otras maniobras fraudulentas para lograr tal finalidad.

En este sentido, la principal conducta abarcada por el tipo penal es la colusión que tiene por objeto la fijación de precios. Para llegar a esta conclusión, a partir del propio texto de la norma, no es necesario incluir una expresión que haga referencia a un determinado conglomerado (como podría ser el caso de la palabra "coligación"). Basta para ello, simplemente, en reparar que el mencionado tipo penal, a la hora de describir sus posibles sujetos activos, se refiere en plural a "los que" realizaren aquellas maniobras fraudulentas. Dicha constatación debería bastar para concluir que el delito permite alcanzar comportamientos colectivos como la colusión. Por lo demás, si esto no fuera suficiente, no veo por qué no podrían utilizarse las normas de la parte general, especialmente aquellas referidas a la coautoría, para abarcar a quienes se coluden para alterar el valor de los bienes y servicios que se transan en los mercados.

De lo anterior no se sigue que el delito del artículo 285 sea uno de "participación necesaria" que requiera un sujeto activo plural. Como se vera más adelante, los mecanismos fraudulentos requeridos por el tipo permiten captar también comportamientos individuales. Por otra parte, el acuerdo de precios, constituye un mecanismo fraudulento idóneo para cometer este ilícito. El origen histórico del delito nos ha demostrado que, bajo las concepciones económicas que inspiraron su surgimiento, el simple pacto entre vendedores, desde antiguo, ha sido considerado como un fraude a la hora de determinar los precios.

Como han puesto de relieve entre otros Del Río ${ }^{99}$, Mera ${ }^{100}$ y Hernández ${ }^{101}$, uno de los sentidos en que el legislador nacional ha utilizado la expresión "fraude" o "medios

\footnotetext{
${ }^{99}$ DEL RÍO, Derecho Penal, cit. nota ${ }^{\circ}$ 2, p. 242.

${ }^{100}$ Sobre este punto, el profesor Mera ha sostenido que "[e]l artículo 286 no ha utilizado, en cambio, el término fraude en el sentido de engaño ni menos en el de abuso de confianza. La significación que propiamente debe asignársele a la voz fraude en este precepto (que lo emplea como sinónimo de medio
} 
SALAZAR, Andrés. "La alteración de precios como fraude. Comentarios acerca del origen histórico del artículo 285 del Código Penal chileno y su interpretación”.

fraudulentos" al momento de incluirlo en los tipos penales, guarda relación con una referencia genérica a cualquier medio ilícito. Esta es, precisamente, la interpretación que aparece como la más consistente con la intención de los legisladores decimonónicos y con las ideas que se encontraban detrás de los precedentes legislativos y doctrinarios de la Europa medieval y moderna, de acuerdo con lo estudiado.

A su vez, el fraude de la colusión debe traducirse en una adulteración del precio natural. Una vez más, en coherencia con la concepción que hemos revisado, por precio natural debe entenderse aquel corriente, esto es, el que se fija a través del libre juego de la oferta y la demanda en un determinado mercado ${ }^{102}$. Por lo tanto, la prueba de la adulteración del precio natural puede realizarse de forma negativa: basta con demostrar que el precio se corresponde más bien con la plasmación de la voluntad conjunta del grupo de actores económicos de que se trata o, en otras palabras, que las acciones del grupo han impedido que el valor de las cosas sea determinado por el normal funcionamiento de las fuerzas del mercado; que el comportamiento del precio guarda correspondencia con los planes del conglomerado o que simplemente quiénes forman parte del acuerdo han dejado de competir entre ellos, a pesar de su supuesta posición de rivalidad en el mercado ${ }^{103}{ }^{104}$.

fraudulento), se desprende del artículo siguiente, el 287, que identifica al medio fraudulento con el medio ilícito". MERA, Fraude civil y penal, cit. nota n 2, p. 90.

${ }^{101}$ HERNÁNDEZ, "La punibilidad de la colusión", cit. nota n ${ }^{\circ}$ 1, p. 154.

${ }^{102}$ En este sentido, debe aclararse que la teoría del precio natural de Adam Smith no sirve para dar otorgar utilidad práctica a la norma del artículo 285 del CP. Y ello es así, porque en Adam Smith (quién mantiene la terminología escolástica, pero otorgándole un nuevo contenido) el precio natural es un precio meramente referencial, el cual no puede variar nunca. Ello es así, porque para Smith, el precio natural se encuentra asociado, básicamente, a los costos de producción y al "legítimo provecho" que el oferente pretende obtener en el mercado. Éste se distingue del precio de mercado que es el que se logra determinar por el sometimiento de los agentes económicos al libre juego de la oferta y la demanda. De ahí que Smith sostenga que el precio de mercado puede ser mayor o inferior al precio natural y que el precio natural pueda mantenerse estable durante un largo período de tiempo. Si esto es así y si el precio natural no hace más que reflejar una verdad necesaria e interna a los costos de producción del específico bien o servicio que se pone a la venta, es obvio que este no puede ser sujeto de manipulación. El precio natural en Smith constituye un concepto meramente descriptivo y su concreción en un caso particular (por ejemplo: "el precio natural de un kilo de pan equivale dos peniques") se manifestaría en un enunciado informativo, de carácter eminentemente fáctico, susceptible de verdad o falsedad, pero, como se ha dicho ya, no podría verse afectado por manipulación o adulteración artificial alguna. De ahí que para respetar el principio de utilidad en la interpretación de las normas jurídicas resulte no sólo más consistente con la tradición del precepto (que ya hemos estudiado más arriba) sino que, además, superior a nivel hermenéutico, entender que la norma en estudio, al referirse al precio natural de los productos, se encuentra designando al precio común o de mercado, tal y como lo sostenían los escolásticos. Por otra parte, ello no implica ninguna distorsión si se tiene en cuenta que, precisamente que el "precio natural" de los escolásticos (esto es, aquel al que hacen referencia los artículos 461 del Código Penal español de 1848 y el Código Penal chileno de 1874) constituye un equivalente funcional al "precio de mercado" postulado por Smith. Ésta, huelga insistir, es la única forma de entender la norma para que ella adquiera operatividad y no arrojarla al sinsentido: entender que el legislador quiso sancionar la adulteración de un objeto que por su propia esencia no se puede manipular. Sobre la teoría del precio del economista escoses, véase: SMITH, Adam, Investigación sobre la naturaleza y causas de la riqueza de las naciones, $2^{\mathrm{a}} \mathrm{Ed}$., Ciudad de México: Fondo Económico de Cultura, 2012, pp. 47-62.

${ }^{103} \mathrm{Si}$ bien es cierto no se puede hablar de un delito de omisión, el contenido del acuerdo fraudulento en un sentido relevante hace referencia a una omisión: se trata de un compromiso adoptado en orden a abstenerse de competir, reemplazando a la concurrencia, como mecanismo legitimo para la determinación de los precios, por el mero arbitrio del conglomerado. 


\section{Polít. crim. Vol. 11, № 22 (Diciembre 2016), Art. 3, pp. 391-438. [http://www.politicacriminal.cl/Vol_11/n_22/Vol11N22A3.pdf]}

A mayor abundamiento, al basarse en una concepción de "medios fraudulentos" en sentido amplio, la norma penal incluye a los fraudes por engaño, lo que implica que el esparcimiento de rumores falsos para adulterar el precio de las cosas, también tiene cabida en esta norma de sanción. Sin embargo, debe enfatizarse el hecho que el agio, tal como se ha visto, no es la única ni la paradigmática forma de cometer este delito. Del mismo modo, son idóneos otros mecanismos fraudulentos para la realización del tipo penal como, por ejemplo, el acaparamiento orientado a la producción de escasez y al alza de los precios ${ }^{105}$.

En estrecha vinculación con lo anterior, se encuentra la prohibición de alterar el precio natural del trabajo.

${ }^{104}$ Sobre este punto la Corte de Apelaciones de Santiago en la ya citada sentencia Rol No 3.139-2015 del 29 de diciembre del 2015, referida al "caso farmacias", en su considerando decimotercero, adopta la posición contraria a la que aquí se expresa y sostiene que el Ministerio Público debería haber acreditado cuál fue el precio natural del producto en el período de colusión. Sin embargo, la Corte pretende exigir una prueba imposible: y es que el precio de mercado (o precio natural), habiendo existido una colusión, constituye una circunstancia que nunca tuvo lugar en el pasado (eso es, en el período de tiempo relevante para el caso sometido a su juzgamiento). De hecho, en la jurisdicción especial de libre competencia el daño anticompetitivo (necesario para estimar las indemnizaciones de los consumidores) sólo puede ser determinado sobre la base de estimaciones: esto es lo que los economistas denominan como "contrafactual". Por lo tanto, incluso para los especialistas el precio de mercado -en estos casos- no constituye sino una hipótesis: se trata de una variable no observable que nunca tuvo (ni pudo tener) una existencia empírica. Para apreciar un ejemplo de los métodos a través de los cuales los economistas buscan determinar "el precio que se habría observado en un escenario contrafactual competitivo", véase: GOMEZ-LOBO, Andrés y LIMA, José Luis, "Estimación de los daños económicos generados por la colusión en la industria de pollos en Chile", Santiago: Facultad de Economía y Negocios de la Universidad de Chile, 2012, pp. 7 y ss.

${ }^{105} \mathrm{Si}$ a pesar de todo se siguiera sosteniendo que la colusión, el acaparamiento, la violencia o la coacción no son constituyen medios fraudulentos en el contexto de los artículos 285 y $286 \mathrm{CP}$, y en caso que el lector crea que lo que procede es una interpretación restrictiva del tipo penal no veo razones que permitan no incluir a la colusión como una forma de engaño concluyente. En este sentido, y para no extenderme necesariamente sobre el punto, aquí se adhiere completamente a lo expuesto por el profesor Héctor Hernández en su trabajo. Al respecto ver: HERNÁNDEZ, "La punibilidad de la colusión”, cit. nota n 1, pp. 154-156. Quizás, solo resta complementar lo allí señalado con las siguientes consideraciones: 1) Siguiendo a Watzalavick, en términos de la Teoría de Comunicación Humana existen dos axiomas especialmente pertinentes para estos efectos: (a) resulta imposible no comunicar y (b) la comunicación puede ser verbal o no verbal (digital o analógica). Sobre los axiomas de la comunicación humana ver: WATZLAWICK, Paul; HELMICK, Janet y JACKSON, Don, Teoría de la Comunicación Humana, Interacciones, Patologías y Paradojas, Barcelona: Editorial Herder, 1985, pp. 49-71; 2) En relación con lo anterior y siguiendo a Mayer entendemos que el engaño concluyente, implica una comunicación; una aserción que "se encuentra implicada en los elementos que definen la relación negocial de la que se trate y sin los cuáles esta dejaría de tener sentido o perdería su razón de ser". Sobre esto véase MAYER, Laura, "El engaño concluyente en el delito de estafa", Revista Chilena de Derecho, Vol. 41 (2014), pp.1031 y ss.; 3) En el caso del derecho chileno de los contratos existen expectativas normativizadas y que en tal calidad otorgan a los consumidores confianza en que ciertos estándares mínimos de legalidad serán cumplidos: así por ejemplo el artículo 22 de la Ley de Efectos Retroactivos de las Leyes indica que en cada contrato se entienden incorporadas las leyes vigentes en el país al momento de celebrarlo: Pues bien, en nuestro país existe una estructura legal que fomenta la libre competencia y castiga la colusión (de precios) y, por lo tanto, quienes se acercan a un distribuidor, celebran un contrato y adquieren un producto, poseen la legítima expectativa de pagar un precio determinado por las fuerzas del mercado y no por el acuerdo de quienes deberían competir por él; 4) en casos tradicionales de colusiones realizadas a nivel de proveedores de consumidores finales, es usual que los coludidos acudan a ofertas para simular la existencia de competencia (incluso se ha recurrido a ofertas falsas como en el "caso farmacias" como forma de coordinar, de manera soterrada, el alza y estabilización del precio de los productos). En este contexto, parece indudable la aptitud los acuerdos colusorios para ser entendidos como fraudes basados en engaño concluyente. 
SALAZAR, Andrés. "La alteración de precios como fraude. Comentarios acerca del origen histórico del artículo 285 del Código Penal chileno y su interpretación”.

Siendo absolutamente trivial la constatación de que la negociación sindical se encuentra totalmente excluida del alcance del tipo penal, la única forma racional de otorgar una interpretación útil a la regla es reconocer que la expresión "medio fraudulento" aquí tampoco se encuentra restringida al engaño o al abuso de confianza.

Una interpretación armónica de las normas contempladas en el párrafo 7 del título VI del Libro II de nuestro Código Penal, entrega un sólido apoyo a esta posición, sobre todo ante la ineludible (y a mí juicio inobjetable) evidencia que aporta el texto del artículo 287 del Código Penal. En efecto, a través de esa disposición, el legislador chileno castiga a quienes "emplearen amenaza o cualquier otro medio fraudulento para alejar a los postores en una subasta pública con el fin de alterar el precio del remate" haciendo equivalentes la amenaza y el fraude ${ }^{106}$.

Pues bien, la referida equivalencia es totalmente extrapolable al caso de la adulteración del precio del trabajo.

Atendida la estrecha relación existente entre los artículos 285 y 287 del Código Penal, resulta totalmente factible entender que el precio natural del trabajo puede ser alterado a través de los medios fraudulentos (ilícitos) coacción o violencia ${ }^{107}$. Por lo demás, esta conclusión es enteramente consistente con la historia de la noción de "precio natural" que ya hemos revisado más arriba ${ }^{108}$ y con la evolución del precepto español del cual proviene el artículo 285 del $\mathrm{CP}^{109}$.

\footnotetext{
${ }^{106}$ En contra de lo aquí sostenido, en el cotexto del "caso farmacias", la Corte de Apelaciones respectiva optó por una interpretación restrictiva del "medio fraudulento" requerido por el art. $285 \mathrm{CP}$, asociándolo a la exigencia de un engaño. El argumento utilizado por la Corte para salir del escollo que pone en su interpretación el claro tenor del artículo 287 CP, es extraordinariamente débil. Según la Corte, el antecedente que impediría entender a la amenaza como un medio fraudulento se encontraría en el mismísimo texto del artículo 287: éste sería la utilización de la letra "o" entre las expresiones "amenaza" y "cualquier otro medio fraudulento". Sin embargo, el uso de aquella letra no tiene el alcance que aquél órgano pretende otorgarle. Y es que, al centrar su análisis en el empleo de la expresión "o" como un argumento concluyente, la Corte descontextualiza dicha palabra y rehúye el sentido total de la expresión utilizada por el legislador, no haciéndose cargo del alcance que debe otorgársele, entonces, a la expresión "cualquier otro medio fraudulento", ya que es aquí donde encontramos la clave para calificar a la amenaza como una especie del género "medios fraudulentos": con la expresión "cualquier otro" el autor de la norma, precisamente, se está refiriendo a medios fraudulentos distintos de la amenaza (incluyendo a su vez, dentro de ese universo, a la esta conducta como un caso especifico de aquéllos).

${ }^{107}$ Sobre este argumento, véase HERNÁNDEZ, "La punibilidad de la colusión”, cit. nota no 1, p. 154.

${ }^{108}$ En efecto, tal y como se vio supra II.1, de acuerdo con la teoría económica escolástica, el precio natural o de mercado, podía ser adulterado ilícitamente por medio de la concurrencia del fraude, la violencia o la coacción.

${ }^{109}$ El primer antecedente histórico de relevancia es de lege ferenda y dice relación con el proyecto de reforma al Código Penal de 1850 encabezado por Francisco Silvela de 1884. En aquel texto (presentado al Congreso español el 21 de diciembre de ese año) se constata que "el delito de maquinaciones para alterar el precio de las cosas, a diferencia del Código de 1870 que castigaba a quienes se coligaren con el fin de encarecer o abaratar abusivamente el precio del trabajo o regular sus condiciones (art. 556) el Proyecto Silvela castiga[ba] solamente a quienes empleen violencia o amenazas o ejercieren cualquier coacción". Sobre esto: ANTÓN ONECA, José, "Los proyectos decimonónicos para la reforma del Código Penal español", Anuario de Derecho Penal y Ciencias Penales, Tomo XXV, Fascículo II (Mayo-Agosto, 1972), p. 268. El segundo antecedente lo podemos encontrar en la circular de la Fiscalía del Tribunal Supremo español del 20 de junio de 1902 en la que se señala que "en uso de la facultad que reconoce el artículo 13 de la Constitución [1876], y
} 
Por último, debe tenerse presente que no todas las conductas anticompetitivas de carácter colusorio que conocemos hoy caben dentro del artículo 285 CP. En este sentido, debe considerarse que dada la restricción típica implicada por el tenor literal de la norma objeto de nuestro estudio, quedan fuera de sanción penal acuerdos colusorios que recaigan en el reparto de cuotas o zonas de mercado, aquellos destinados a reducir las cantidades de producidas o los que se encuentran destinados a boicotear procesos de licitación, entre otras conductas anticompetitivas, a no ser, claro está, que dichos acuerdos tengan trascendencia directa en el precio de las cosas ${ }^{110}$.

\section{Excurso: Algunas consideraciones finales.}

Antes de finalizar este trabajo, conviene detenerse en ciertas consideraciones teóricoconceptuales e históricas que podrían ser útiles de tener a la vista a la hora de evaluar adecuadamente el alcance de las disposiciones estudiadas y su concreto potencial de aplicabilidad.

\section{1. ¿Posee alguna importancia para la aplicación del tipo penal el concebir o no la norma como una disposición tributaria del moderno derecho "antitrust" norteamericano?}

Luego de lo revisado en las páginas precedentes, al lector podrían parecerle pertinentes preguntas como las que siguen: ¿Cuáles son las causas del olvido de las categorías conceptuales de la economía escolástica, su concepción del monopolio y de las conductas colusorias?; ¿Por qué se ha podido llegar a pensar que la persecución penal de los carteles resulta ser una invención del derecho norteamericano, creado en las postrimerías del S. XIX?; y por último: ¿tiene algún tipo de relevancia, para el aplicador de la norma jurídica, el hecho de que las categorías conceptuales incorporadas al texto de la norma penal en estudio hayan sido superadas y reemplazadas, en la actualidad, por conceptos de mayor sofisticación y capacidad explicativa?

En primer lugar, tal y como señala de Roover, probablemente una de las causas que ha provocado que no se tome en cuenta el estudio de la tradición económica escolástica, podría provenir de la consolidación de una serie de prejuicios erigidos en contra de la

cumplido lo que dispone la ley de asociaciones de 1887 , los trabajadores se asocian y coligan para fin tan humano como el de mejorar las condiciones del trabajo con que atienden al diario sustento, la asociación es perfectamente lícita, y si se produce huelga o la abstención colectiva del trabajo, se ejercita un derecho que no puede ser cohibido ni sometido a juicio mientras no surja la excepción que para el abuso, es decir, para la violencia y la amenaza, establece el art. 556 [450 del Código de 1848] del Código tantas veces citado". Este antecedente En: CUERDO/SÁNCHEZ, “Tradiciones penales", cit. nota n 44, pp. 319 y 320. Finalmente, cabe agregar que la Ley de Huelgas y Coligaciones del 27 de abril de 1909 derogó el artículo 556 del Código Penal español, reconociendo el derecho de asociación sindical y a negociar colectivamente.

${ }^{110}$ En principio, podría pensarse que la fijación de precios predatorios, por la vía de un acuerdo colusorio, sea que se imponga como barrera de entrada o sea como conducta estratégica destinada a la eliminación del resto de los competidores del mercado, quedaría incluida dentro del texto del artículo 285 del CP. Sin embargo, una reducción teleológica de la norma, planteada sobre la base de la comprensión de ésta como una regla que protege los derechos de los consumidores, no podría dar cabida al reproche penal de dicho comportamiento, ya que, al menos en el corto plazo, los demandantes se verían beneficiados por la puesta en práctica de dicho acuerdo. En dicha medida, una conducta como la descrita sólo quedaría cubierta por la prohibición administrativa del Art. $3^{\circ}$ del DL 211. 
SALAZAR, Andrés. "La alteración de precios como fraude. Comentarios acerca del origen histórico del artículo 285 del Código Penal chileno y su interpretación”.

cultura de aquella época, lo que podría haber llevado a los investigadores a obviar todo antecedente que, desde un punto de vista retrospectivo, vaya más allá de la modernidad ${ }^{111}$. 112 .

Respecto de la segunda cuestión, Piotrowski, atribuye el olvido de la larga tradición jurídica europea en la lucha contra los carteles a la difusión e influencia que adquirieron ciertas publicaciones alemanas, austriacas y norteamericanas de fines de siglo XIX que, producto de su falta de rigurosidad, creyeron ver en la existencia de estos acuerdos un fenómeno nuevo, surgido en el ámbito de dichas sociedades, en el contexto de la revolución industrial $^{113}$.

Otro tanto, quizás, pueda deberse a la enorme influencia que tuvo después de la segunda guerra mundial la implantación del modelo norteamericano de defensa de la libre competencia en Alemania, el cual fue visto, desde un principio, como una importante herramienta para luchar contra los grandes cárteles que se habían establecido en la economía de ese país durante la dictadura nacionalsocialista. La nueva política procompetencia, sus instituciones y conceptos, probablemente, hicieron olvidar aún más la herencia normativa a que hemos hecho alusión ${ }^{114}$.

No obstante, a mi juicio, en el caso que nos convoca, puede existir una explicación tan pertinente como las anteriores. Y es que, nuestras categorías conceptuales actuales (en particular, aquellas desarrolladas por el derecho "antitrust" norteamericano a partir del siglo pasado) ostentan un potencial explicativo mucho mayor de aquel que poseían los constructos desarrollados por los economistas medievales. Qué duda cabe que hoy podemos dar cuenta de manera mucho más precisa y completa de los grandes alcances sistémicos que posee la colusión. Dicha situación es comprendida en la actualidad como una grave falla de mercado, de la cual solo se siguen ineficiencias, sin que la ciencia económica haya sido capaz de encontrar evidencia alguna respecto de consecuencias positivas que atribuirle a dicho tipo de acuerdos. A mayor abundamiento, conceptos como poder de mercado, posición dominante, barreras de entrada, economías de escala o desarrollos conceptuales como la teoría de la organización industrial o la teoría de los juegos, nos permiten conocer de mejor forma las causas, incentivos y efectos de las prácticas monopólicas.

En esta medida, no puede existir controversia respecto de la superioridad del paradigma actualmente dominante en comparación con aquel construido por los economistas escolásticos. Ello porque, a pesar de que ambos paradigmas son inconmensurables en sus propios términos, la superioridad del primero con respecto del segundo puede comprobarse

\footnotetext{
${ }^{111}$ DE ROOVER, “La Teoría”, cit. nota n 14, pp. $171-172$.

112 Respecto de estos prejuicios véase: SCHUMPETER, Joseph, "Ciencia e ideología”, El Trimestre Económico, Vol. 17, № 65; (Enero-Marzo 1950), pp. 7-8 y 19-20.

${ }^{113}$ Entre otros autores, Piotrowski nombra el caso de Schoenlank, quien, sin ningún apoyo científico habría llegado a proclamar que el día 09 de mayo de 1873, en la ciudad de Viena, habrían sonado las campanas que anunciaban el nacimiento de los carteles". Otros autores criticados son Kleinwächter y Menzel. PIOTROWSKI, Cartels and Trusts, cit. nota n ${ }^{\circ} 38$, pp. 11-86.

${ }^{114}$ Para un panorama relativo a estos hechos, véase BUXBAUM, Hannah, "German legal culture and the globalization of competition law: A historical perpective on the expansion of private antitrust enforcement". Berkeley Journal of International Law, Vol. 23 (2005), pp. 474 y ss.
} 


\section{Polít. crim. Vol. 11, No 22 (Diciembre 2016), Art. 3, pp. 391-438. \\ [http://www.politicacriminal.cl/Vol_11/n_22/Vol11N22A3.pdf]}

fácilmente a través de la siguiente constatación: si bien la moderna teoría de la competencia, haciendo uso de su propio arsenal conceptual, permite comprender completamente las premisas y los esquemas explicativos desarrollados por el paradigma escolástico, el paradigma escolástico, recurriendo a su propio campo conceptual, no es capaz de dar cuenta del paradigma actualmente dominante ${ }^{115}$.

Sin embargo, de la anterior constatación no se sigue nada, de manera forzosa, para la labor judicial. Y ello es así, porque el derecho no es una ciencia empírica ${ }^{116}$.

A diferencia de las ciencias naturales, el Derecho no trabaja con referencia exclusiva a datos empíricos con miras a explicar la realidad "bruta" a través del descubrimiento de leyes de la naturaleza, o de dar cuenta de ciertos fenómenos a partir de dichas regularidades $^{117}$; el juez, opera con un tipo de ontología totalmente distinto, la cual se encuentra construida a partir de "meras" convenciones sociales, convenciones cuya principal característica es que se encuentran institucionalmente fijadas por medio del lenguaje $^{118}{ }_{-}^{119}$. En otras palabras, dada la función que le ha sido asignada al juez por ordenamiento jurídico, el marco teórico más relevante para su labor es el texto de la norma jurídica. Y mientras la letra de la ley, a pesar de su desactualización científica, permita describir (o cubrir) el mismo fenómeno empírico cuya comprensión teórica se ha

${ }^{115}$ Respecto a la incomensurabilidad entre paradigmas rivales, véase KHUN, Thomas, La estructura de las revoluciones científicas, $3^{\mathrm{a}}$ Ed., Ciudad de México: Fondo de Cultura Económico, 2012, pp. 264 y ss. Respecto a la comparabilidad racional entre paradigmas rivales a través de una transición entendida como ganancia comprensiva véase MACINTYRE, Alasdair, "Epistemological crises, dramatic narrative and the philosophy of science", The Monist, Vol $60 \mathrm{~N}^{\circ} 4$ (Octubre, 1977), pp. 453-472; también TAYLOR, Charles, "La explicación y la razón práctica", en: EL MISMO, Argumentos Filosóficos: Ensayos sobre el Conocimiento, el Lenguaje y la Modernidad. Barcelona: Editorial Paidós, 2012, pp. 59-90.

${ }^{116}$ A partir de esta constatación y aún cuando puedan trazarse ciertas similitudes entre el trabajo de un juez y de un científico, en la medida en que ambos subsumen "hechos" en "leyes" que sirven de premisas para el respectivo razonamiento, debe advertirse inmediatamente que existen diferencias fundamentales entre ambas operaciones. Una concepción en la que se asimila a la subsunción judicial con la actividad del científica es desarrollada en extenso por FERRAJOLI, Luigi, Derecho y Razón, teoría del garantismo penal, $8^{\text {a }}$ Edición, Madrid: Editorial Trotta, 2006, pp. 47-70. En primer lugar, mientras las leyes científicas son esencialmente refutables por medio de la demostración de que éstas son inadecuadas para explicar o predecir un determinado fenómeno, las leyes que sirven de premisa para el razonamiento judicial no pueden ser refutadas por esa vía y sólo perderán vigencia por medio del acto institucional de la derogación. En segundo lugar, mientras las leyes de la naturaleza se verifican o comprueban por medio del trabajo del científico, (juicio que se basa fundamentalmente en variables de tipo observacional) las leyes del hombre (normas jurídicas) se interpretan. En otras palabras, cada vez que el científico refuta o verifica el potencial explicativo o predictivo de una determinada teoría, pone en cuestión la vigencia (universal) de dicha teoría; Por su parte, el juez que interpretando la ley, rechaza la subsunción de los hechos en la norma no pone en cuestión la vigencia general de ésta: simplemente decide que ese caso particular no es abarcado por el tenor literal posible de esa ley. Por lo tanto, si en el ámbito científico la descripción de un determinado fenómeno empírico ha cambiado por el surgimiento de una nueva teoría, es obvio que el científico deberá adaptarse a este nuevo escenario, abandonar la teoría superada y trabajar desde el nuevo paradigma.

${ }^{117}$ En relación con la importancia del lenguaje observacional para la ciencia véase CARNAP, Rudolf, "The Methodological Character Theoretical Concepts", Minnesota Studies in the Philosophy Science, Vol 1 (1956), pp. 38-75.

${ }^{118}$ En relación con la ontología propia de lo social, y con especial referencia a lo normativo, véase SEARLE, John, La Construcción de la Realidad Social, Barcelona: Editorial Paidós, 1997, pp. 49-92.

${ }^{119}$ En relación con la cientificidad del Derecho y su metodología, véase: LARENZ, Karl, Metodología de la Ciencia del Derecho, Barcelona: Editorial Ariel, 2010, pp. 177 y ss.; BASCUÑÁN RODRÍGUEZ, Antonio, "Observaciones sobre la ciencia del Derecho", Revista de Derecho y Humanidades, N 6 (1998), pp. 15-25. 
SALAZAR, Andrés. "La alteración de precios como fraude. Comentarios acerca del origen histórico del artículo 285 del Código Penal chileno y su interpretación”.

perfeccionado en el ámbito científico, no existe detrimento alguno para la vigencia de la norma jurídica ni para la labor judicial.

Y esto es así, precisamente porque la labor de la jurisdicción no se agota en la caricaturesca y reduccionista analogía que la vinculaba meramente a la imagen de una boca que pronuncia las palabras de la ley: la adjudicación depende de un ejercicio interpretativo y el juez se encuentra investido de los poderes institucionales pertinentes para darle contenido a las expresiones incluidas en las normas jurídicas. Es más, dicha labor no sólo es facultativa, sino que se corresponde precisamente con el más fundamental de sus deberes: "decir el derecho" (iuris dictio) ${ }^{120}{ }_{-}^{121}$.

En este orden de ideas, si entendemos que la interpretación jurídica es "la operación o conjunto de operaciones, mediante las que se trata de asignar sentido a los enunciados jurídicos" y se admite que en dicho proceso posee una importancia innegable "el contexto del enunciado jurídico de que se trate" ${ }^{22}$, el lector podrá apreciar que el esfuerzo que se ha desarrollado durante este trabajo, precisamente, reside en contextualizar nuestro delito de alteración de precios en la tradición histórica, económica y jurídica a la que pertenece, circunstancia a partir de la cual se ha planteado una exégesis de la norma que sigue siendo reconocible como un sentido posible del enunciado legal en que se encuentra inserto.

Y en el caso en análisis, luego de lo estudiado resulta evidente que, detrás de la fórmula semántica utilizada por el legislador chileno en los textos de los artículos 285 y 286 del Código Penal, se encuentra una clara prohibición de las conductas colusivas orientadas a la fijación de precios.

Es por esta razón que resulta ser tan importante comprender las raíces y el contenido de conceptos como "precio natural", "fraude" o "maniobra fraudulenta": la clarificación de estas expresiones nos han ayudado a entender que en Chile se encuentran sancionados penalmente, a título de fraude, los acuerdos de fijación de precios suscritos entre sujetos que "compiten" en un mismo mercado.

\footnotetext{
${ }^{120}$ En este sentido, véase ATRIA, Fernando, "Jurisdicción e independencia judicial: El poder judicial como poder nulo", Revista de Estudios de la Justicia, № 5 (2004), pp. 119-141.

${ }^{121}$ Ahora bien, lo verdaderamente trascendente de esta reflexión, aparentemente trivial, reside en la constatación de la relación interna que existe entre el fenómeno jurídico y lenguaje: es que, el lenguaje, dada su ductilidad, permite describir un mismo hecho o una misma conducta de las más diversas formas (claro está, en la medida en que ello sea gramatical y semánticamente factible). El hecho de que las normas puedan ser expresadas de múltiples maneras en un determinado lenguaje, ha llevado a los autores a postular una clara diferencia entre lo que es una norma y su formulación. Fundamental, VON WRIGHT, Georg, Norma y Acción, una investigación lógica, Madrid: Editorial Tecnos, 1970, pp. 109 y ss.; Así, por ejemplo, las expresiones "no se admiten vehículos en el parque"; "los vehículos están prohibidos en este parque" o "debe estacionar su automóvil fuera del parque", constituyen "tres formulaciones diferentes de una regla y no tres reglas", sobre esto: SCHAUER, Frederick, Las Reglas en Juego, Madrid: Marcial Pons, 2004, p. 122.

${ }^{122}$ SILVA SÁNCHEZ, Jesús María, "Sobre la interpretación "teleológica” en el Derecho Penal”, en: DIAZ, Miguel y GARCÍA, Juan Antonio (Eds.), Estudios de Filosofía del Derecho Penal, 2a Ed., Bogotá: Universidad del Externado, 2006, pp. 368-369. Véase también: LARENZ, Metodología, cit. nota nº 119, pp. 192-196.
} 


\section{Polít. crim. Vol. 11, № 22 (Diciembre 2016), Art. 3, pp. 391-438. \\ [http://www.politicacriminal.cl/Vol_11/n_22/Vol11N22A3.pdf]}

En resumen, habiendo considerado todas las circunstancias hermenéuticamente relevantes, el tipo penal contenido en los artículos 285 y 286 del CP se muestra, gramatical, sistemática y teleológicamente consistente con la prohibición de las colusiones orientadas a la fijación artificial de los precios de los bienes, conclusión que se extrae desde el texto (autoritativo) de la ley, único antecedente ineludiblemente vinculante para la labor jurisdiccional ${ }^{123}$.

\section{2. ¿Posee alguna relevancia para la aplicación del tipo penal el hecho de que algunos autores o autoridades nacionales hayan desconocido la idoneidad que posee el artículo 285 CP para captar y sancionar algunas conductas que restringen la competencia?}

Finalmente, podría surgir una duda de tipo pragmático, relacionada con la actitud que adoptaron distintos agentes gubernamentales y expertos frente a las normas penales que han sido objeto del presente estudio. El cuestionamiento al que nos referimos podría formularse del siguiente modo: ¿por qué si los artículos 285 y 286 del CP constituyen normas aptas para captar ilícitos anticompetitivos, éstos habrían sido sistemáticamente ignorados o expresamente desestimados por distintas autoridades y especialistas en la materia?

En este orden de ideas, en la reciente discusión dogmática referida a la aplicación de este delito se ha enarbolado como un argumento decisivo, para negar la aplicabilidad de las citadas disposiciones a casos de colusión, la actitud adoptada por algunos comentaristas y autoridades públicas al momento de incorporarse a nuestro ordenamiento jurídico la Ley $\mathrm{N}^{\mathrm{o}}$ 13.305 en el año 1959.

En esta dirección, se han citado algunas opiniones emitidas por importantes personeros de aquella época, como por ejemplo, las formuladas Ministro de la Excelentísima Corte Suprema don Eduardo Varas o las del Ministro de Justicia don Enrique Ortúzar, quienes fueron contestes en aseverar que la nueva legislación habría incorporado por primera vez en nuestro país normas penales destinadas a castigar atentados en contra de la libre competencia $^{124}$.

Sin embargo, el potencial explicativo de un esquema argumentativo cimentado en fundamentos como los expuestos, debe ser fuertemente relativizado pues, de la opinión que una autoridad tenga respecto de las normas que componen el derecho vigente, no se sigue necesariamente consecuencia alguna respecto de la validez o aplicabilidad de las aquéllas. $\mathrm{Y}$ es que, en primer lugar, aunque parezca una obviedad, un argumento como éste nos obliga a recordar que, por muy importante que sea una determinada persona o autoridad, sus opiniones no poseen, en modo alguno, validez contrafáctica ${ }^{125}$. En otras palabras, del

\footnotetext{
${ }^{123}$ Sobre este punto véase: MACCORMICK, Neil, "Argumentación e Interpretación en el Derecho", DOXA No 33 (2010), pp. 69-75; RAZ, Joseph, Entre la Autoridad y la Interpretación, Madrid: Marcial Pons, 2013, pp. 103-136. Acerca de la legitimación de la jurisdicción por la vía de su vinculación a la ley véase: ATRIA, Fernando, "Legislación, jurisdicción, administración", en: VV.AA., Una vida en la Universidad de Chile. Celebrando al profesor Antonio Bascuñán Valdés, Santiago: Legal Publishing, 2013, pp. 160 y ss.

${ }^{124}$ MATUS, "De nuevo sobre", cit. nota $\mathrm{n}^{\circ}$ 1, pp. 317-318. A dichas opiniones, según este autor, se añadiría la omisión de todo tipo de referencias a los artículos 285 y $286 \mathrm{CP}$ en que incurre el Mensaje enviado por el Gobierno y que culminó con la dictación de la Ley $\mathrm{N}^{\mathrm{a}} 13.305$.

${ }^{125}$ Recuérdese que la existencia o inexistencia de una norma es un hecho, que puede ser descrito a través de una proposición normativa, proposición que, por lo tanto, puede tener valor de verdad o falsedad.
} 
SALAZAR, Andrés. "La alteración de precios como fraude. Comentarios acerca del origen histórico del artículo 285 del Código Penal chileno y su interpretación”.

hecho de que las autoridades citadas hayan desconocido la vigencia de una ley (e ignorado su ámbito de aplicación) no se sigue la inexistencia o la invalidación de aquélla.

Al mismo tiempo, resulta necesario destacar que otros autores nacionales, en el mismo contexto temporal, sí creyeron encontrar en el artículo 285 del CP una norma penal capaz de captar ilícitos anticompetitivos. En este sentido, por ejemplo, podemos citar la opinión del profesor Oscar Aramayo ${ }^{126}$ o, sin ir más lejos, la posición adoptada, en épocas más recientes, por el propio profesor Domingo Valdés ${ }^{127}$.

Pero la cita de estas últimas opiniones no tiene como propósito exhibir un contrapunto que tienda a equilibrar el contexto dialéctico posterior a la dictación del Código Penal chileno; Con lo anterior lo único que se pretende es reafirmar la poca sustantividad de un argumento como éste, el cual se basa en interpretaciones particulares realizadas en un escenario marcado por el disenso.

Por otra parte, existe una serie de antecedentes históricos, muy bien documentados, que podrían permitir entregar una explicación objetiva al desuso y posterior olvido que afectó a las normas penales contenidas en los artículos 285 y 286 CP. Esta explicación tiene su fundamento en el difícil escenario económico vivido por nuestro país con posterioridad a la crisis del año 1929. A partir de este evento y a consecuencia de la inflación, la cesantía y la gran carestía social que afectó a nuestra población, los Gobiernos de la época adoptaron una agenda política basada en una intensa intervención Estatal en todas las áreas de la economía. El rasgo más característico de dicha actividad se manifestó en una decidida política de fijación de precios por parte del Gobierno en distintos rubros, sobre todo en aquellos mercados donde los objetos transados fueron considerados como "bienes de primera necesidad". Dichas políticas sociales se extendieron incluso hasta los años sesenta $^{128}$.

\footnotetext{
${ }^{126}$ Este autor, sostuvo en el año 1964 que el artículo 285 del Código Penal podría tener aplicación en casos de especulación ilícita, entendiendo por tal "un término genérico, que comprende distintas figuras delictivas consistentes en maniobras para alterar el comercio normal de las mercaderías"ARAMAYO, Oscar, Régimen Legal de Comercio Interno Chileno, Santiago: Editorial Jurídica de Chile, 1964, pp. 89-90.

${ }^{127}$ VALDÉS, Libre Competencia y Monopolio, cit. nota n ${ }^{\circ} 76$, pp. 225 y ss.

${ }^{128}$ En efecto, en nuestro país existió hasta el último cuarto del siglo pasado una constante política de fijación de precios en distintos ámbitos de la economía nacional. La mencionada estrategia económica se agudizó en nuestro país durante los años que siguieron al estallido de "la gran depresión" de 1929. La inflación que afectó a los Gobiernos de principios del S. XX y los alarmantes niveles de cesantía que impactaron a nuestra sociedad llevó a que éstos decretaran la estabilización forzosa de los niveles de ciertos y determinados bienes (considerados como "de primera necesidad"), dejando de lado a la ley de la oferta y la demanda como mecanismo naturalmente idóneo la determinación del valor de las cosas. Así, el DL 520 del 31 de agosto de 1932 creó al denominado "Comisariato General de Subsistencias y Precios", institución que tenía a su cargo, entre otras finalidades "el control de la calidad y precio de los artículos de primera necesidad y de uso o consumo habitual". Por su parte, el DL 7.747 de 1943 facultó al presidente de la República para fijar los precios de los artículos agropecuarios de producción nacional, previo informe del Instituto de Economía Agrícola. En el año 1953 los Decretos con Fuerza de Ley № 88 y 173, traspasaron las facultades de fijación de precios que poseía el Comisariato General a una nueva Superintendencia de Abastecimientos y Precios. Finalmente, en el año 1960, a través del D.F.L. 242 el Gobierno creó a la Dirección de la Industria y el Comercio (DIRINCO), institución que sustituyó a la Superintendencia de Abastecimientos. Acerca de estas regulaciones y del mecanismo y formalidades necesarios par la fijación de precios véase: ARAMAYO, Régimen Legal, cit. nota $\mathrm{n}^{\circ} 126$, pp. 17 y ss. Este escenario perduró hasta fines del segundo gobierno de
} 


\section{Polít. crim. Vol. 11, № 22 (Diciembre 2016), Art. 3, pp. 391-438. \\ [http://www.politicacriminal.cl/Vol_11/n_22/Vol11N22A3.pdf]}

En un ambiente como éste, se hace más factible comprender las razones que llevaron a los legisladores del año 59 y a algunos miembros de la comunidad, a valorar la nueva regulación como una revolución de alcances inéditos en la historia nacional.

A este factor de tipo político-económico, debemos agregar uno que exploramos en el acápite anterior: la nueva legislación antitrust se inspiraba en el paradigma impuesto por la economía neoclásica y en las aportaciones realizadas por la naciente econometría. Ambas perspectivas aportaron una explicación mucho más técnica del fenómeno monopólico, por lo que se dio en nuestro país, al igual que en otras latitudes, el mismo margen para pensar que la sanción penal de los cárteles constituía una innovación jurídica.

Sin embargo, ya hemos visto que constituye una grave equivocación el asumir que la represión de la colusión constituye una conquista del siglo $\mathrm{XX}^{129}$.

En resumen, una argumentación construida sobre la base de opiniones aisladas y descontextualizadas de autoridades o agencias estatales emitidas con posterioridad a la entrada en vigencia de las normas que se analizan dista mucho de ser decisiva.

El principal déficit que un argumento de autoridad como el citado enfrenta reside en que éste es incapaz de negar que el artículo $285 \mathrm{CP}$ dice lo que dice y que sanciona lo que puede sancionar.

\section{Conclusiones.}

Nuestros artículos 285 y 286 del Código Penal sancionan una especie de acuerdos colusorios: aquellos que alteran el precio de los bienes y servicios que pueden ser objeto de contratación.

Carlos Ibáñez del Campo quien, en medio de la crisis económica que afectó a su Gobierno, decidió contratar a la denominada "Misión Klein-Sacks", economistas norteamericanos que, entre otras sugerencias, propusieron terminar con las políticas de fijación de precios e incorporar una moderna legislación antitrust. Producto de esta última recomendación, precisamente surgió la Ley $\mathrm{N}^{\circ}$ 13.305. Véase también BERNEDO, "Historia", cit. nota $\mathrm{n}^{\circ} 91$, pp. 29-38.

${ }^{129}$ Finalmente, si de amnesia interpretativa se trata, en materia de prohibiciones penales referidas a maniobras destinadas a alzar los precios contamos con varios ejemplos. Permítaseme citar algunos de ellos. En primer lugar, cabe hacer presente que el decreto ley 520 del año 32 contemplaba una serie de disposiciones penales en contra de quienes realizaren maniobras de especulación, acaparamiento, ocultamiento o destrucción de bienes de primera necesidad, con el fin de alterar sus precios al alza (artículos 48 y siguientes). Este dato, hasta donde alcanzo a ver, ha sido sistemáticamente ignorado por nuestra reciente doctrina. Pero quizás el más llamativo de todos los olvidos ("legislativos") en la materia lo encontramos en la dictación del Decreto Ley N $N^{\circ} 280$ del 24 de enero de 1974, que estableció normas en resguardo de la actividad económica nacional. Esta ley no sólo sancionó penalmente a quienes cobrasen un precio superior al fijado o autorizado por el organismo competente (artículo $2^{\circ}$ ), sino que además estableció en su artículo $4^{\circ}$ un delito cuya pena podía alcanzar al presidio mayor en cualquiera de sus grados en contra de quien "acapare u oculte artículos esenciales, el que los destruya o elimine del mercado, con objeto de obtener para sí o para otros una ventaja comercial". Pues bien, lo increíble de esta ley es que fue dictada tan sólo unos meses después de que entrase en vigencia el D.L. 211, que sancionaba penalmente (y con una formula bastante amplia) a conductas que entorpecieran la libre competencia (!) siendo las captadas por el D.L. 280, precisamente, formas paradigmáticas de restringir el comercio. 
SALAZAR, Andrés. "La alteración de precios como fraude. Comentarios acerca del origen histórico del artículo 285 del Código Penal chileno y su interpretación”.

Los distintos conceptos contenidos en la ley se vuelven mucho más claros y su referencia más efectiva, si ellos son leídos de conformidad con la profunda tradición económica a la que pertenecen.

En primer lugar, los precios naturales que son susceptibles de adulteración son aquellos que corresponden al precio de mercado, esto es, aquellos fijados por la estimación común que realiza la colectividad de conformidad con las fuerzas de la oferta y la demanda en un determinado mercado relevante.

Por su parte, de manera consistente con las concepciones que se encuentran detrás de los conceptos utilizados por el legislador, el acuerdo de precios realizado por los competidores constituye fraude. Lo anterior resulta coherente con una acepción amplia de los "medios fraudulentos", posición interpretativa que posee una importante tradición en nuestro país.

De otro lado, el que hemos estudiado es un delito que protege las legítimas expectativas de los consumidores en la correcta formación de los precios de conformidad con el normal juego de la oferta y la demanda, sin que medien en ello factores ajenos a la libre confluencia de estas fuerzas, en atención a las propias características de los bienes y las del concreto mercado de que se trate. Si bien esto se vincula con algunos aspectos que ocupan a lo que hoy denominamos como libre competencia, no se corresponde del todo con aquel concepto.

Al mismo tiempo, creo haber demostrado cuál fue la real intención que tuvo el legislador al momento de decidir la exclusión de la referencia a las coligaciones en la redacción definitiva del tipo penal del artículo 285 del CP. Además, he demostrado que libre concurrencia y libre competencia, son conceptos del todo equivalentes. De lo expuesto se sigue que ambos factores son irrelevantes para la correcta interpretación del tipo penal.

De todo lo anterior se deduce que, a pesar de su anacronismo, el delito de adulteración fraudulenta de precios aún tiene un lugar que ocupar en nuestro derecho penal económico. $\mathrm{Y}$ es que, como hemos visto, a través de él pueden sancionarse las colusiones de empresarios que tienen por objeto la fijación del precio de las cosas que son objeto de contratación.

Pero al mismo tiempo, es ese anacronismo, plasmado en su texto, la principal característica que demuestra la actual necesidad de buscar una regulación penal moderna que sea capaz de alcanzar al resto las conductas colusivas más graves, especialmente aquellas que habitualmente se tienden a agrupar bajo la denominación de "hardcore cartels"130.

Dicha actualización resulta especialmente imperiosa en una economía como la chilena, que ha sido institucionalmente diseñada sobre la base de una exacerbada confianza en los mercados como mecanismos eficientes para la distribución de riquezas en la sociedad. De ahí que el monopolio y la colusión requieran por parte de nuestra legislación una respuesta

\footnotetext{
${ }^{130} \mathrm{Y}$ es que, en atención al tenor literal de nuestros artículos 285 y 286 del CP quedarían fuera del ámbito penal conductas colusivas habitualmente incluidas en esta categoría de cárteles, como aquellos acuerdos que tienen por objeto la repartición de cuotas de mercado o las originadas para afectar procesos de licitación.
} 
Polít. crim. Vol. 11, No 22 (Diciembre 2016), Art. 3, pp. 391-438.

[http://www.politicacriminal.cl/Vol_11/n_22/Vol11N22A3.pdf]

consistente con dicha definición, como ocurre, por ejemplo, en los países de raigambre anglosajona.

Por ahora, en el tiempo que resta hacia la actualización de la legislación nacional, los artículos 285 y 286 del Código Penal pueden, al menos, ser útiles para la persecución penal de los acuerdos de precios que se celebren entre competidores, defraudando las legítimas expectativas de los consumidores de encontrar en los mercados, precios de bienes y servicios que sean establecidos, lisa y llanamente, por las condiciones normales de competencia que imperan, naturalmente, en dichos mercados. 
SALAZAR, Andrés. "La alteración de precios como fraude. Comentarios acerca del origen histórico del artículo 285 del Código Penal chileno y su interpretación”.

\section{BIBLIOGRAFÍA.}

Actas de las sesiones de la Comisión Redactora del Código Penal chileno, Santiago: Imprenta de la República de Jacinto Nuñez, 1873

AGÜERO, Francisco, "Nuevos elementos para el debate sobre el bien jurídico libre competencia", Boletín Latinoamericano de Competencia, № 19 (Noviembre 2004).

ALMANZA PASTOR, José Manuel, "La huelga laboral en España tras la modificación del artículo 222 del Código Penal español”, Revista de Política Social, No 72 (1996).

AMERICAN BAR ASOCIATION, Market Power Handbook. Competition Law and Economic Foundations, Estados Unidos: ABA Publishing, 2005.

ANTÓN ONECA, José, "Los proyectos decimonónicos para la reforma del Código Penal español”, Anuario de Derecho Penal y Ciencias Penales, Tomo XXV, Fascículo II (Mayo-Agosto, 1972), p. 268

, "El Código Penal de 1848 y D. Joaquín Francisco Pacheco", Anuario de Derecho Penal y Ciencias Penales, Tomo XIX, Fascículo III (1966).

ARAMAYO, Oscar, Régimen Legal de Comercio Interno Chileno, Santiago: Editorial Jurídica de Chile, 1964.

ATRIA, Fernando, "Jurisdicción e independencia judicial: El poder judicial como poder nulo", Revista de Estudios de la Justicia, No 5 (2004).

, "Legislación, jurisdicción, administración", En: VV.AA., Una vida en la Universidad de Chile. Celebrando al profesor Antonio Bascuñán Valdés, Santiago: Legal Publishing, 2013.

BASCUÑ̂́N RODRÍGUEZ, Antonio, "Observaciones sobre la ciencia del Derecho", Revista de Derecho y Humanidades, № 6 (1998).

, "Sobre la distinción entre derogación expresa y derogación tácita", Anuario de Filosofía Jurídica y Social, № 18 (2000).

BERNEDO, Patricio, Historia de la libre competencia en Chile. 1959-2010, Santiago: Ediciones Fiscalía Nacional Económica, 2013.

BOBBIO, Norberto, Teoría General del Derecho, Bogotá: Editorial Temis, 1987.

BORK, Robert, The Antitrust Paradox: A policy at war with itself. New York: Basic Books, 1978.

BRAGE, Santiago, "Los Delitos de alteración de precios en nuestro derecho histórico", Dereito $\mathrm{N}^{\circ} 9$ (2000).

BRAVO LIRA, Bernardino, "La vigencia de las Partidas en Chile", Revista de Estudios Histórico-Jurídicos, Vol. 10 (1985).

, "El derecho indiano después de la independencia en América española", Historia, Vol. N 19 (1984).

BUXBAUM, Hannah, "German legal culture and the globalization of competition law: A historical perspective on the expansion of private antitrust enforcement", Berkeley Journal of International Law, Vol. 23 (2005).

CARNAP, Rudolf, "The Methodological Character Theoretical Concepts", Minnesota Studies in the Philosophy Science, Vol. 1 (1956).

COURCELlE-SENEUIL, Jean Gustave, "Economía Política", Revista del Pacífico, Tomo I (1858).

COUYOUMDJIAN, Juan Pablo, "Importando modernidad. La evolución del pensamiento económico en Chile en el siglo XIX”, Historia N$^{\circ}$ 48, Vol. 1 (enero-junio 2015). 
Polít. crim. Vol. 11, No 22 (Diciembre 2016), Art. 3, pp. 391-438.

[http://www.politicacriminal.cl/Vol_11/n_22/Vol11N22A3.pdf]

COWEN, Denis, "A survey of the law relating to the control of monopoly in South Africa", South African Journal of Economics, Vol. 18 (Junio 1950).

CUERDO, Miguel y SÁNCHEZ, Dolores, “Tradiciones Penales en la maquinación para alterar el precio de las cosas", Anuario de Historia del Derecho Español, T. LXXXIV (2014).

DE ALCALÁ, Luys, Tractado de los prestamos que passan entre mercaderes y tractantes y por consiguiente de los logros/cambios/compras adelantadas y ventas al fiado, Toledo, 1546.

DE LUGO, Ioannis, Disputationes de Iustitia et Iure, Tomus Secundus, Lyon: Sumpt. Philippi Borde, Laurentii Arnaud et Claudii Rigaud, 1646.

DE MOLINA, Luis, Disputationes de Contractibus in Quibus Omnes, Atque Difficultates ad Hanc Materiam Pertinentes Resolutae, ac fumma con diligentia decisae adeò videntur, Venecia: Apud Matthiam Collosinum, \& Baretium Baretium, 1601.

, La Teoría del Precio Justo, CAMACHO, Francisco (Ed.), Madrid: Editora Nacional, 1981.

DE ROOVER, Raymond, "La Teoría del Monopolio antes de Adam Smith: Una revisión”, Revista del Centro de Estudios Públicos, Nº 25 (1987).

, "Economía Escolástica”, Revista del Centro de Estudios Públicos, No 9 (1983).

, San Bernardino of Siena and San Antonino of Florence. Two great economic thinkers of the middle ages, Boston: Harvard Graduate School of Business Administration, 2008.

DEL RÍO, Raimundo, Derecho Penal, Santiago: Editorial Nacimiento, 1935, T. III.

ESPINOZA, Hernán, "La Academia de Leyes y Práctica Forense", Anales de la Universidad de Chile, $\mathrm{N}^{\circ}$ 65-65 (1947).

ETCHEBERRY, Alfredo, Derecho Penal, $3^{a}$ Edición, Santiago: Editorial Jurídica de Chile, 1998, T. IV.

FELIÚ, Daniel, El Trabajo y las Huelgas de Obreros. Conferencias dadas en la escuela de adultos titulada "Blas Cuevas", Valparaíso: Imprenta de la Patria, 1873.

FERNÁNDEZ, Pedro Javier, Código Penal de la República de Chile esplicado y

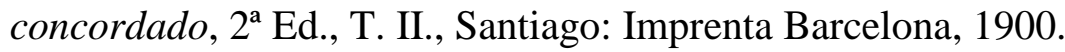

FERRAJOLI, Luigi, Derecho y Razón, teoría del garantismo penal, $8^{\text {a }}$ Edición, Madrid: Editorial Trotta, 2006.

FOX, Eleanor, "The efficiency paradox", en: PITOFSKY, Robert (Ed.), How the Chicago School Overshot the Mark: The effect of Conservative Economic Analysis on U.S. Antitrust, New York: Oxford University Press, 2008.

FUENSALIDA, Alejandro, Concordancias i comentarios del Código Penal chileno, Lima: Imprenta Comercial, 1883.

GARCIA CAVERO, Percy, Los Delitos contra la Competencia, Lima: Ara, 2004.

GOMEZ-LOBO, Andrés y LIMA, José Luis, "Estimación de los daños económicos generados por la colusión en la industria de pollos en Chile", Santiago: Facultad de Economía y Negocios de la Universidad de Chile, 2012.

GONZÁlEZ ARCE, José, Gremios. Producción artesanal y mercado, España: Universidad de Murcia, 2000.

GORDON, Barry, Economic Analysis before Adam Smith: Hesiod to Lessius, Londres: Macmillan, 1975. 
SALAZAR, Andrés. "La alteración de precios como fraude. Comentarios acerca del origen histórico del artículo 285 del Código Penal chileno y su interpretación”.

GRICE-HUTCHINSON, Marjorie, The School of Salamanca. Readings in spanish monetary theory, 1544-1605, Londres: Oxford University Press, 1952.

GROIZARD, Alejandro, El Código Penal de 1870, Concordado y Comentado, Tomo VII, Salamanca: Esteban-Hermanos, Impresores, 1897.

HERNÁNDEZ, Héctor, "La punibilidad de la colusión (secreta) de precios en el derecho chileno", Polit. Crim, Vol. 7, No 13 (julio, 2012).

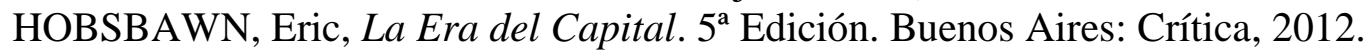

HYLTON, Keith, Antitrust Law. Economic Theory and Common Law Evolution, Boston: Cambridge University Press, 2003.

KHUN, Thomas, La estructura de las revoluciones científicas. $3^{\mathrm{a}}$ Ed., Ciudad de México: Fondo de Cultura Económico, 2012.

KOVACIC, William y SHAPIRO, Carl, Antitrust Policy: A century of economic and legal thinking, Journal of Economic Perspectives, Vol. 14, No 1 (2000).

LABATUT, Gustavo, Derecho penal, T. II., $7^{\text {a }}$ Ed., Santiago: Editorial Jurídica de Chile, 1983.

LANGHOLM, Odd, "Monopoly and market irregularities in medieval economic thought: traditions and text to A.D. 1500", Journal of the History of Economic Thought, Vol. 28, No 4 (2006).

LARENZ, Karl, Metodología de la Ciencia del Derecho, Barcelona: Editorial Ariel, 2010.

LASTRA, José Manuel, "Las corporaciones de oficio y la libertad de asociación en Francia”, Revista de la Facultad de Derecho de México, T. XLIX, No 223-224 (1999).

LIEFMANN, Robert, "Monopoly or competition as basis of a government trust policy", Quarterly Journals of Economics, $\mathrm{N}^{\mathrm{o}} 29$ (1915).

LONDONOO, Fernando, "Aproximación histórico-comparada al Título VIII de la Ley de Mercado de Valores: bases para el reconocimiento de un contenido antimanipulativo". Polít. crim. Vol. 10, No 20 (Diciembre 2015).

MACCORMICK, Neil, "Argumentación e Interpretación en el Derecho", en: DOXA № 33 (2010).

MACINTYRE, Alasdair, "Epistemological crises, dramatic narrative and the philosophy of science", The Monist, Vol 60, № 4 (Octubre 1977).

MARX, Karl, El Capital. Crítica de la Economía Política, T. I, $3^{\text {a }}$ Ed., Ciudad de México: Fondo de Cultura Económico, 2010.

MATUS, Jean Pierre, "Acerca de la actual falta de punibilidad en Chile de los acuerdos de precios". Polit. crim. Vol. 7, No 14 (Diciembre, 2012).

, "De nuevo sobre la falta de punibilidad en Chile de los atentados contra la libre competencia de conformidad con el Art. 285 del Código penal. Algunos aspectos de la discusión con Héctor Hernández en Política Criminal”, Polít. crim. Vol. 7, № 14 (Julio, 2013).

MAYER, Laura, "El engaño concluyente en el delito de estafa", Revista Chilena de Derecho, Vol. 41 (2014).

McNULTY, Paul, "A note on the history of perfect competition", Journal of Political Economy, Vol. 75, № 4 (1967).

MELTZER, Bernard, "Labor unions, collective bargaining and the antitrust law", Journal of Law and Economics, $\mathrm{N}^{\circ} 152$ (1963). 
Polít. crim. Vol. 11, No 22 (Diciembre 2016), Art. 3, pp. 391-438.

[http://www.politicacriminal.cl/Vol_11/n_22/Vol11N22A3.pdf]

MERA, Jorge, Fraude Civil y Penal. El delito de entrega fraudulenta, $2^{\mathrm{a}}$ Ed., Santiago: Editorial Conosur, 1994.

MEYNET GONZÁLEZ, Alfredo, Estudio Histórico de las Reformas Constitucionales de la Administración Errázuriz Zañartu (1871-1876), Memoria para optar al grado de licenciado de ciencias jurídicas y sociales. Santiago: Universidad de Chile. 1946

MILL, John Stuart, Principios de Economía Política. $2^{\mathrm{a}}$ Ed., Ciudad de México: Fondo de Cultura Económica, 2006.

MONTESQUIEU, Del espíritu de las leyes, México: Purrúa, 1997.

MORRIS, William (Ed.), The American Heritage Dictionary of The English Language, Boston: Houghton Mifflin Company, 1976.

NOVOA, Eduardo, "La legislación penal económica". En: VV.AA., La nueva legislación y el desarrollo económico de Chile, Santiago: Editorial Universidad Católica, 1962.

PACHECO, Joaquín Francisco, El Código Penal. Concordado y comentado, T. III. $5^{\text {a Ed., }}$ Madrid: Imprenta Santiago, 1881.

PAGE, William, "Standard Oil and U.S. Steel: Predation and Collusion in the Law of Monopolization and Mergers", Southern California Law Review Vol. 85, No 3(2012).

PIOTROWSKI, Roman, Cartels and Trust; Their Origin and Historical Development, Londres: George Allen \& Unwin LTD, 1933.

POPESCU, Oreste, "Aspectos analíticos en la doctrina del justo precio de Juan de Matienzo (1520-1579)”, Cuadernos de Economía y Ciencias Empresariales, № 25 (1993).

"El pensamiento económico en la escolástica hispanoamericana", Económica, Vol. XXXII, No 2 (Julio- Diciembre, 1986).

RAMÍREZ NECOCHEA, Hernán, Obras Escogidas. Balmaceda y la contrarrevolución de 1981. Historia del movimiento obrero en Chile. Vol. I., Santiago: Editorial LOM.

RAMOS PÉREZ-OLIVARES, Alfredo, "Aproximación histórica al tratamiento de la huelga en la España preconstitucional”, Saberes, Vol. No 4 (2009).

RAZ, Joseph, Practical Reason and Norms, Nueva York: Oxford University Press, 2002. Entre la Autoridad y la Interpretación, Madrid: Marcial Pons, 2013.

REAL ACADEMIA DE LA HISTORIA, Las Siete Partidas del Rey Alfonso el Sabio. Cotejadas con varios códices antiguos (glosadas por Gregorio López), Tomo III, Cuarta y Quinta Partida, París: Leiconte y Lesserre Editores, 1843

RIESENFELD, Stefan, "The legal protection of competition in France", California Law Review, Vol. 48 (Octubre, 1960).

SAY, Jean-Baptiste, Tratado de Economía Política. Ó exposición sencilla del modo con que se forman, distribuyen y se consumen las riquezas, Tomo II, $4^{\mathrm{a}}$ Edición, Madrid: Imprenta de don Francisco Martínez Dávila, 1821.

SCHAUER, Frederick, Las Reglas en Juego, Madrid: Marcial Pons, 2004.

SCHUMPETER, Joseph, "Ciencia e ideología”, El Trimestre Económico, Vol. 17, № 65 (Enero-Marzo 1950).

Historia del Análisis Económico, Barcelona: Editorial Ariel, 2012.

SEARLE, John, La Construcción de la Realidad Social, Barcelona: Editorial Paidós, 1997.

SMITH, Adam, Investigación sobre la naturaleza y causas de la riqueza de las naciones, $2^{\mathrm{a}}$ Ed., Ciudad de México: Fondo Económico de Cultura, 2012.

STIGLER, George, "Perfect competition, historically contemplated", Journal of Political Economy, Vol. 65 (Febrero 1957). 
SALAZAR, Andrés. "La alteración de precios como fraude. Comentarios acerca del origen histórico del artículo 285 del Código Penal chileno y su interpretación”.

TAYLOR, Charles, "La explicación y la razón práctica", en: EL MISMO, Argumentos Filosóficos: Ensayos sobre el Conocimiento, el Lenguaje y la Modernidad. Barcelona: Editorial Paidós, 2012.

VALDÉS, Domingo, Libre Competencia y Monopolio, Santiago: Editorial Jurídica, 2006.

VILlALOBOS, Sergio, Los Comienzos de la Historiografía Económica de Chile, 18621940, Santiago: Editorial Universitaria, 1981.

VON FEUERBACH, Paul Johann, Tratado de Derecho Penal Común Vigente en Alemania, Buenos Aires: Editorial Hammurabi, 1989.

VON WRIGHT, Georg, Norma y Acción, una investigación lógica, Madrid: Editorial Tecnos, 1970.

VV.AA., El Ladrillo. Las bases de la política económica del gobierno militar, 2a Edición, Santiago: Centro de Estudios Públicos (1992).

WALKER, Francis, "The law concerning monopolistic combination in continental Europe", Political Science Quarterly, Vol. 20, N 5 (Marzo 1905).

WATZLAWICK, Paul; HELMICK, Janet y JACKSON, Don, Teoría de la Comunicación Humana, Interacciones, Patologías y Paradojas, Barcelona: Editorial Herder, 1985.

WEBER, Max, Economía y Sociedad, 2 ${ }^{\mathrm{a}}$ Edición, Ciudad de México: Fondo de Cultura Económico. 2008.

WOOD, Diane, El Pensamiento Económico Medieval, Barcelona: Editorial Crítica, 2003. 